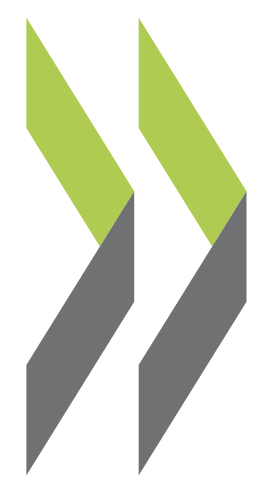

OECD Economics Department Working Papers No. 259

Knowledge, Technology and Economic Growth: Recent Evidence from OECD Countries

Andrea Bassanini, Stefano Scarpetta, Ignazio Visco 


\section{Unclassified}

Organisation de Coopération et de Développement Economiques

Organisation for Economic Co-operation and Development

ECONOMICS DEPARTMENT
ECO/WKP(2000)32

OLIS : 13-Oct-2000

Dist. : 20-Oct-2000

\section{KNOWLEDGE, TECHNOLOGY AND ECONOMIC GROWTH: RECENT}

EVIDENCE FROM OECD COUNTRIES

ECONOMICS DEPARTMENT WORKING PAPERS NO. 259

by

Andrea Bassanini, Stefano Scarpetta and Ignazio Visco

Most Economics Department Working Papers beginning with No. 144 are now available through OECD's Internet Web site at http://ww.oecd.org/eco/eco. 


\begin{abstract}
RÉSUMÉ
In this paper we present an international comparison of growth trends in the OECD countries, with a special attention to developments in labour productivity - allowing for human capital accumulation - and multifactor productivity (MFP) - allowing for changes in the composition of fixed capital. An attempt is also made to identify both the embodied (in particular in ICT equipment) and disembodied components of technical progress. The possible relation between improvements in MFP and the accumulation of knowledge (as proxied by R\&D expenditures) is discussed, and some tentative policy considerations are advanced, mainly with reference to general framework conditions that might have a bearing in fostering technological changes.
\end{abstract}

The main conclusions are that some "traditional" factors lay behind the disparities in growth patterns across the OECD countries. In particular, they refer to the ability of countries to employ their labour force. There also seem to be some new factors behind growth performance, especially in connection with the diffusion of ICT and related increases in MFP growth rates in the United States. However, it is too early to say whether, even in the United States, the more recent pick-up in the (disembodied) component of MFP may also be related to the presence of spillover and network effects.

JEL classification: $\mathrm{N} 10, \mathrm{O} 47$

Keywords: Economic growth, productivity, investment, general purpose technologies

$* * * * *$

Dans cette étude nous présentons une comparaison internationale des performances en matière de croissance dans les pays de l'OCDE. Une attention est tout particulièrement donnée à la productivité du travail, en tenant compte de l'accroissement du capital humain, et à la productivité multifactorielle (PMF), en tenant compte des changements dans la composition et la qualité du capital physique. L'étude essaye d'identifier la part du progrès technique qui est incorporée dans le capital physique et la part qui ne l'est pas. Le lien potentiel entre les améliorations de la productivité multifactorielle et l'accumulation des connaissances (mesurée de manière approchée par les dépenses en R-D) est aussi examiné, et certaines considérations d'ordre politique sont proposées, concernant surtout les conditions cadre générales qui peuvent améliorer le progrès technique.

L'étude suggère que des facteurs traditionels sont à l'origine des disparités entre les taux de croissance des pays de l'OCDE. En particulier, la capacité d'employer des personnes en âge de travailler varie beaucoup à travers les pays. Il y a aussi de nouveaux facteurs, liés surtout à la diffusion des technologies de l'information et de la communications aux États-Unis. Cependant, il est trop tôt pour conclure que, même aux États-Unis, l'augmentation récente de la productivité multifactorielle est en relation avec la présence d'effets d'entraînement et de réseau.

Classification JEL: N10, O47

Mots-Clés: Croissance économique, productivité, investissement, technologie à utilisation générique

Copyright: OECD 2000

Applications for permission to reproduce or translate all, or part of, this material should be made to: Head of Publications Service, OECD, 2 rue André-Pascal, 75775 PARIS CEDEX 16, Paris. 


\section{TABLE OF CONTENTS}

\section{KNOWLEDGE, TECHNOLOGY AND ECONOMIC GROWTH: RECENT EVIDENCE FROM OECD}

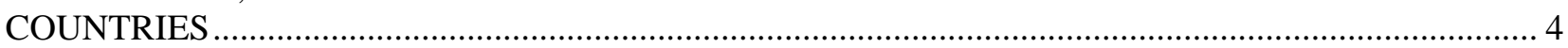

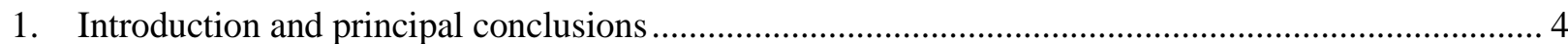

2. Basic facts about recent economic growth in the OECD countries ................................................ 6

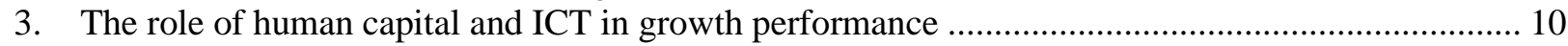

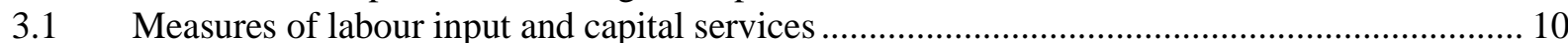

3.2 Evidence on the effects of changes in the composition and quality of labour and capital ....... 12

4. Estimates of multi-factor productivity and the "embodiment" controversy .................................... 17

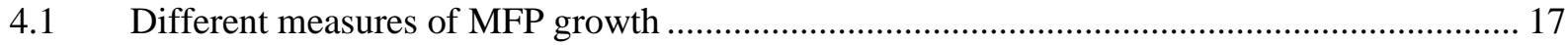

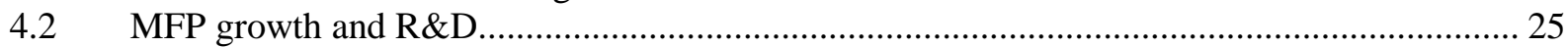

4.3 Does theory help us to explain the productivity slowdown and recovery? ............................ 27

5. Some policy considerations with reference to framework conditions............................................ 28

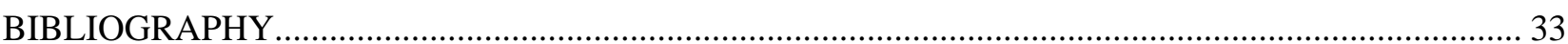




\title{
KNOWLEDGE, TECHNOLOGY AND ECONOMIC GROWTH: RECENT EVIDENCE FROM OECD COUNTRIES
}

\author{
Andrea Bassanini, Stefano Scarpetta and Ignazio Visco ${ }^{1}$
}

\section{Introduction and principal conclusions}

The impressive performance of the US economy in recent years and the ongoing rapid diffusion of information and communications technology (ICT) at a global level have led a growing number of commentators to conclude that we have entered a "new economy". While this is a rather elusive concept, there are at least two dimensions associated to it that are amenable to a factual analysis: $i$ ) the emergence of a higher overall non-inflationary trend productivity growth; and ii) the increase in the role of ICT as the leading factor behind observed changes in the organisation of production and exchange.

In this paper we draw upon a recent body of evidence, with particular reference to material produced in the context of an ongoing OECD project on growth. ${ }^{2}$ We present an international comparison with special attention given to developments in trends of labour productivity, allowing for human capital accumulation, and multifactor productivity (MFP), allowing for changes in the composition of fixed capital. In this context an attempt is made, where possible, to identify both the embodied (in particular in ICT equipment) and disembodied components of technical progress. The possible relation between improvements in MFP and the accumulation of knowledge (as proxied by R\&D expenditures) ${ }^{3}$ is also discussed, and some tentative policy considerations are advanced, mainly with reference to general framework conditions that might have a bearing in fostering technological changes.

1. OECD, Economics Department. The views expressed in this paper are those of the authors and do not necessarily represent those of the OECD or of its Member countries. We thank Phil Hemmings and Paul Schreyer for helpful discussions and Jørgen Elmeskov, Mike Feiner, Dirk Pilat and Andrew Wyckoff for useful comments. Catherine Chapuis Grabiner provided excellent statistical assistance. Previous versions of this paper were presented at two conferences: the $150^{\text {th }}$ Anniversary Conference of the National Bank of Belgium on "How To Promote Economic Growth in the Euro Area" (Brussels, May 11-12, 2000); and the XII Villa Mondragone Conference on "Knowledge Economy, Information Technology and Growth" (Rome, June 26-28, 2000). We thank participants for their comments. The paper is forthcoming in Smets J. and M. Dombrecht (eds), "How to Promote Economic Growth in the Euro Area", Cheltenham, United Kingdom and Northampton, MA, USA: Edward Elgar.

2. Data are from the OECD Analytical Database (ADB) with a number of adjustments to improve crosscountry comparability. For more details see Scarpetta et al. (2000) and Schreyer (2000) as well as the extended version of this paper (Bassanini et al., 2000).

3. It should be observed that improvements in human capital are also importantly related to the emergence of a knowledge economy. In a similar vein, R\&D activity interacts with ICT in supporting higher overall growth, in what is most likely a highly complementary process. 
The principal results of this paper may be summarised as follows:

- Per capita GDP growth was uneven across the OECD in the 1990s, with continued slowdown in most countries, but with a few notable exceptions, among which, remarkably, the United States.

- Contrary to that of GDP per capita, the overall dispersion in labour productivity growth rates remained fairly stable over the 1990s as compared to the 1980s. The explanation for these seemingly conflicting patterns is the diversity in the trends in labour utilisation: higher growth rates in output were accompanied by improvements in the utilisation of labour. This has been the case not only in the United States, but also in Australia, Ireland, Netherlands and Norway. Moreover, the increase in labour productivity seems to reflect in most of these countries significant technological changes, and these appear to be correlated with changes in the intensity of $R \& D$ expenditures.

- In other countries where labour productivity has also picked up, this has been associated with a fall in employment. In most European countries this has taken place in the context of a substantial up-skilling of the workforce. In the United States (but also in Australia and in the Netherlands), this factor has played a minor role, as favourable labour market conditions and reforms have widened the employment base and helped the low-skilled to increase their employment rates.

- Allowing for changes in the composition of capital services (i.e. for shifts towards more productive capital) also explains part of the rise in output growth. This is certainly associated to the rapid investment in ICT that is especially, if not only, observed in the United States.

- Substantial variation in MFP growth rates is also observed across countries. In most of them they have been relatively stable until recently. In Australia, Canada, Denmark, Finland, Norway and Sweden, as well as in the United States, a relevant increase appears to have taken place. However, in Sweden and in Finland, increases in MFP growth rates have been accompanied by a significant slowdown in economic activity and a fall in employment. In other countries, including the major EU economies, trend MFP growth has significantly decreased.

- The growth patterns in the United States include higher growth of GDP per capita, labour and multifactor productivity in a context of higher labour utilisation. These are rather unusual for a country that is already at the world productivity frontier in many industries. Evidence is accumulating to suggest that a large fraction of the productivity recovery in the US is due to the diffusion of ICT, especially in the most recent years. ICT has driven overall productivity growth directly by the boost of MFP growth in the ICT-producing industry itself, and indirectly via capital deepening in ICT equipment by other sectors. The overall process of MFP growth with the slowdown in the 1970s and early 1980s and the subsequent recovery driven by ICT is also consistent with a class of theoretical models that points to slow diffusion of new technologies and slow learning.

These observations suggest that some "traditional" factors lay behind the disparities in growth patterns across the OECD countries. In particular, they refer to the ability of countries to employ their labour force. In this area both national authorities and international organisations (including the OECD) have formulated reform strategies aimed at improving the functioning of labour and product markets so as to foster employment. There also seem to be some new factors behind growth performance, as best exemplified by the US experience. These new factors largely refer to ICT and pose new challenges to 
policy makers. We have identified a number of policy-relevant questions that deserve a closer look. These include: What are the interactions between innovation and diffusion of ICT and public and private R\&D? How do overly restrictive regulations affect the start-up of new, generally small, ICT-related enterprises? Are some financial systems more adequate than others to support ICT-related activities?

To conclude, there is some evidence that supports the perception that something new is taking place, especially in connection with the diffusion of ICT and related increases in MFP growth rates. However, it is too early to say whether, even in the United States, the more recent pick-up in the (disembodied) component of MFP may be also related to the presence of spillover and network effects (of the Internet/e-commerce type) or is mostly (if not only) a cyclical effect. It should anyway be observed that also in this case the increase is likely linked, via a possibly excessive market evaluation of high-tech companies, to perceived technical progress. But this seems all that we may say if, as Mr Gradgrind in Charles Dickens' Hard Times, we "stick to facts". Is then, all this, evidence enough of a "new economy", as seems to be defined in popular newspapers and magazines? Perhaps not, or not yet, or perhaps yes, but then a qualified yes. It seems likely, however, that the possibilities offered by communication networks are still largely to be exploited, even in the United States. And higher, sustainable, rates of growth would in that case become justified. The issue might then be how to make them widespread, and further analysis is needed to assess what the proper framework conditions should be.

\section{Basic facts about recent economic growth in the OECD countries}

A key issue in an international comparison of growth performance is how to treat differences in business cycle conditions across countries. The option generally used in the literature is to compare average growth rates over sufficiently long time periods to minimise cyclical influences. However, this approach has become insufficient in the recent past because of the lack of synchronisation in countries' business cycles, even over 5-year periods, as exemplified by demand conditions in the 1990s in the United States, on the one hand, Continental Europe and, especially, Japan, on the other. In an attempt to tackle this issue, the analysis in this paper largely relies on trend series as opposed to actual series. Trend series have been estimated using an extended version of the Hodrick-Prescott filter (Hodrick and Prescott, 1997). The extended H-P filter tries to overcome the well-known in sample phase shift problem by prolonging actual data out of the sample using the observed average growth rate over the 1980-98 period (Butler, 1996). Given the objective of estimating recent growth patterns, this way to solve the end-point problem can be considered as a prudent approach. In fact it underestimates sharp deviations from the historical pattern in the neighbourhood of the end of the sample. On the other hand, its estimates can be considered as a lower bound in the case of acceleration of the growth rate in the most recent years (or vice versa in the case of deceleration). ${ }^{4}$

Figure 1 suggests that trend GDP per capita growth rates slowed down in the 1990s as compared to the previous decade in the OECD-24 area (i.e. excluding the five countries that joined the OECD in the 1990s). ${ }^{5}$ This aggregate pattern, however, hides persistent differences across countries. Amongst the G-7, the United States actually reversed the slowdown in growth performance observed during the 1970s and 1980s, while most of the other countries had stable or even falling growth rates. Outside the G-7, however,

4. It should be stressed, however, that actual GDP growth rates are broadly consistent with those based on trend series. Moreover, a detailed sensitivity analysis of trend series using variants of the extended H-P filter also yielded broadly consistent results. For more details see Scarpetta et al. (2000).

5. Trend growth rates in GDP per capita are more relevant than trend GDP growth rates from a national living standard perspective although, given the modest demographic changes, the latter broadly match the former. However, there is some evidence that disparities in overall GDP growth increased in the 1990s relative to the 1980 s by less than those in GDP per capita. 
several smaller OECD countries were also able to reverse the slowdown (most notably Australia, Denmark, Ireland, the Netherlands and Norway). Disparities in growth performance have been particularly marked within Europe.

To shed light on the driving forces behind aggregate GDP per capita growth rates we decompose them into three broad categories: $i)$ the demographic effect due to changes in the ratio of persons of working age (15- 64 years) to the total population; ii) the labour productivity effect, measured by changes in the output/employment ratio; and iii) the labour utilisation factor, measured by changes in the employment rate. This decomposition is presented in Figure 2 for most OECD countries over the period 1990-98.

While changes in the composition of the population have had only a minor (often negative) effect on the observed changes in GDP per capita growth, the other two factors, i.e. labour productivity and labour utilisation, have been the two driving forces. Labour productivity growth accounts for at least half of GDP per capita growth in most OECD countries and considerably more than that in many of them. It picked up in a number of countries compared with the 1980s, including the United States, Australia, Denmark, Norway, Portugal - where it was associated with stable or rising employment - and in Germany, Finland, Sweden - where it was associated with falling employment. Notwithstanding differences in labour productivity growth rates across countries, it is noticeable that the overall dispersion did not change in the 1990 s as compared with the 1980s, despite the significant widening of GDP per capita growth rates discussed above.

A key factor to reconcile growing disparities in GDP per capita growth rates in a context of broadly stable differences in labour productivity growth is a divergence in the shares of the working-age population in employment. The 1990s witnessed striking differences in the evolution of employment rates: amongst the major economies, notably, increases in the United States and Japan contrast sharply with declines in Germany, France and Italy. Even stronger contrasts are found among some smaller countries; strong upward trends in employment rates in Ireland and the Netherlands compared with declines in Finland and Sweden. 
Figure 1. Trend growth of GDP per capita in the OECD area over the past two decades Average annual rates of change

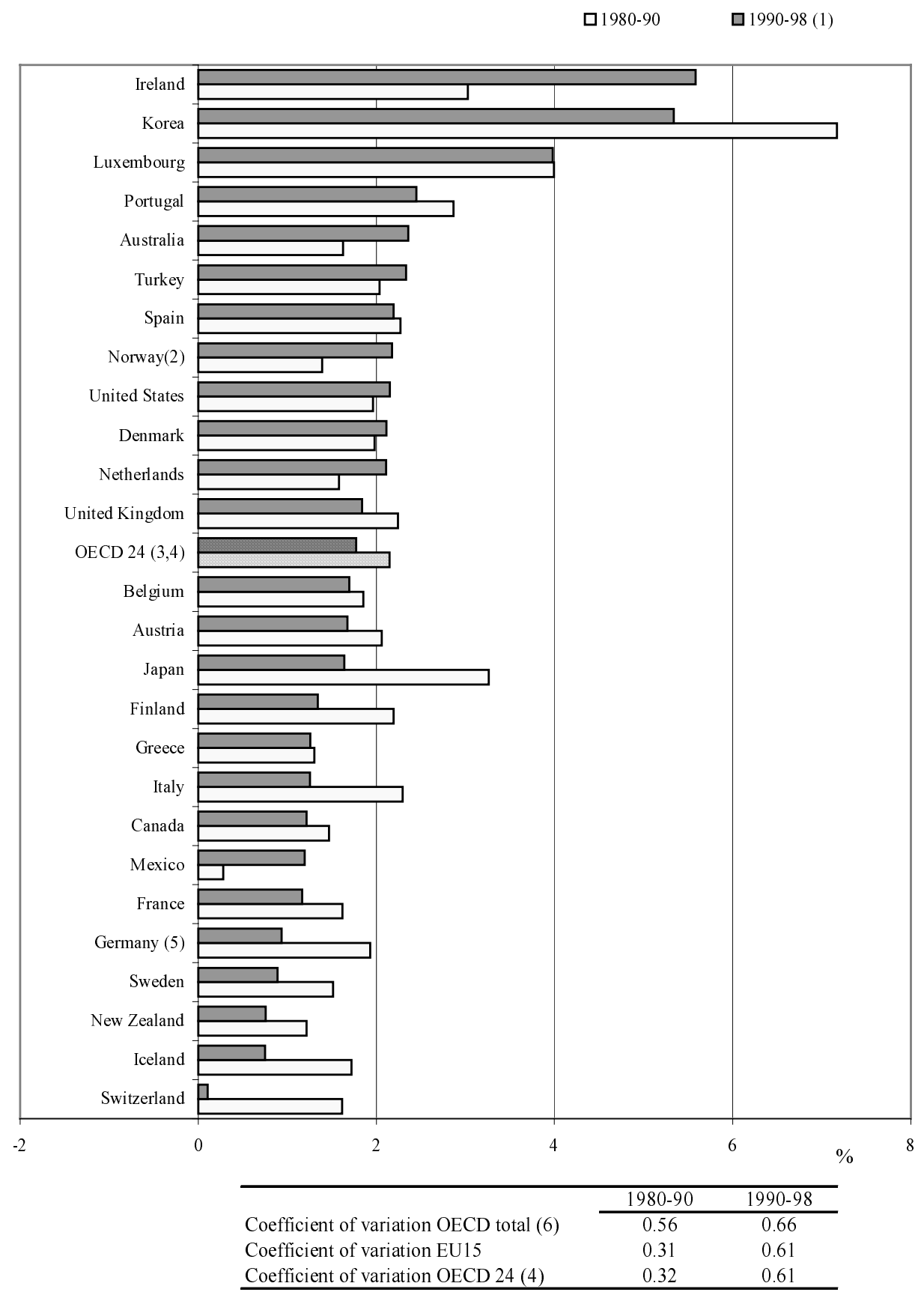

1. 1990-97 for Iceland and Portugal, 1991-98 for Germany.

2. Mainland only,

3. Growth rate for OECD 24 is computed as a weighted average of country growth rates, using country GDP levels expressed in 1993 EKS PPPs as weights.

4. Excluding Czech Republic, Hungary, Korea, Mexico and Poland.

5. Western Germany for 1980-90.

6. Excluding Czech Republic, Hungary and Poland.

Source: Scarpetta et al. (2000). 
Figure 2. Decomposition of trend GDP per capita growth, 1990-98

Average annual rates of change

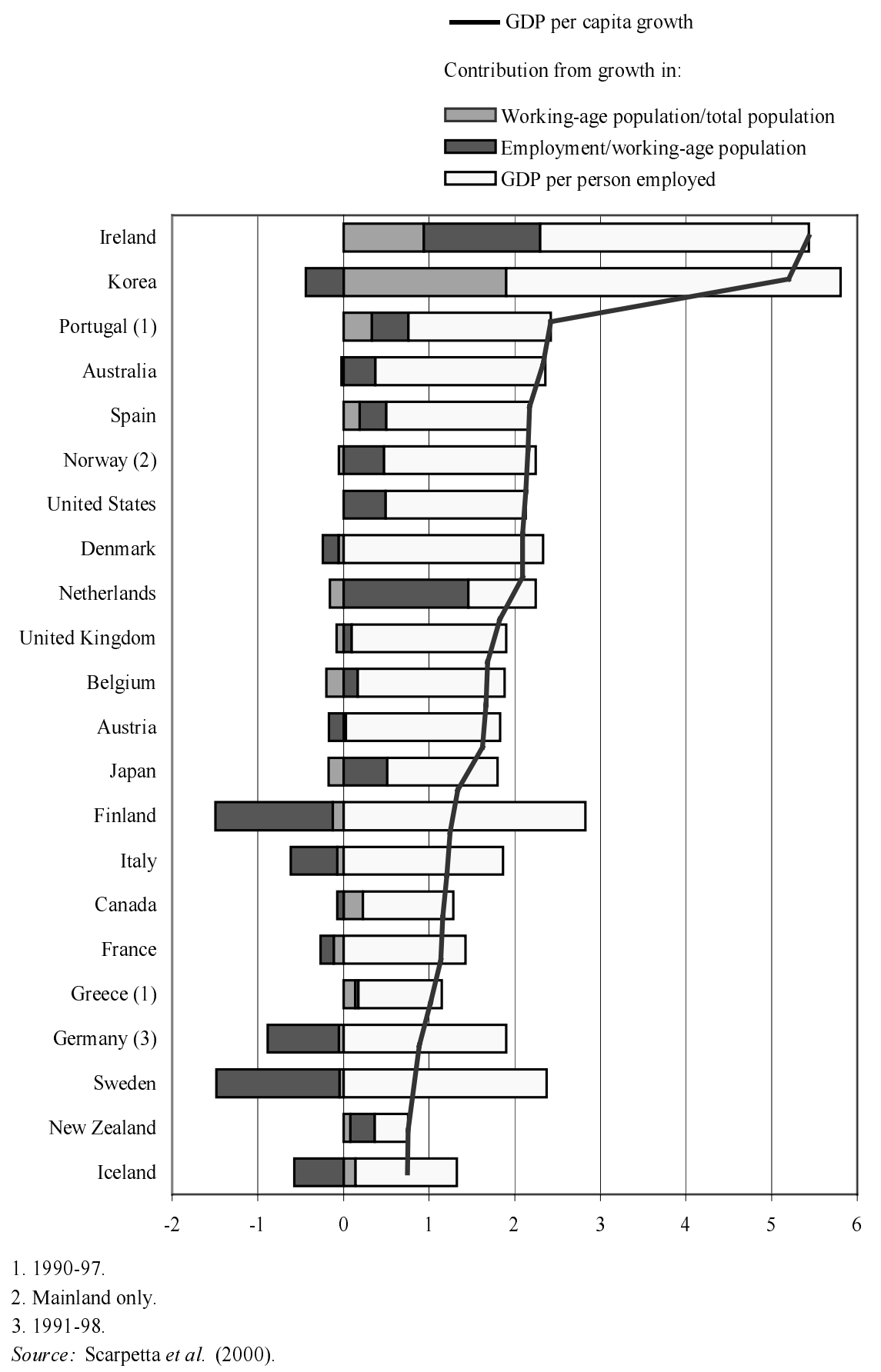




\section{The role of human capital and ICT in growth performance}

In order to assess the impact of labour and capital in output and productivity growth rates, proper account should be made of the role that each factor plays as input in the production process. In the case of the labour input, the simple count of hours worked is only a crude approximation insofar as workers show great differences in education, experience, sector of activity and other attributes that greatly affect their marginal productivity. In particular, a measure of labour input in efficiency units can be obtained by weighting different types of labour by their marginal contribution to the production activity in which they are employed. Since these productivity measures are generally not observable, information on relative wages by characteristics is used to derive the required weights to aggregate different types of labour. The resulting measure of labour input can be quite different from a simple aggregate of total hours or total persons (Dean et al., 1996). The difference between the weighted and unweighted series yields an index for the compositional change of labour input, or its quality.

Jorgenson (1963, 1966), Griliches (1963) and Jorgenson and Griliches (1967) were the first to develop aggregate capital input measures that took the heterogeneity of assets into account: they defined the flow of quantities of capital services individually for each type of asset, and then applied asset-specific user costs as weights to aggregate across services from the different types of assets. User costs are prices for capital services and, under competitive markets and equilibrium conditions, these prices reflect marginal productivities of the different assets. User cost weights are thus a means to incorporate differences in the productive contribution of heterogeneous investments as the composition of investment and capital changes. Changes in aggregate capital input therefore have two distinct sources - changes in the quantity of capital of a given type, and changes in the composition of the various types of assets with different marginal products and user costs (Jorgenson, 1966).

\subsection{Measures of labour input and capital services}

Given a set of observations on different types of factor inputs, $F_{j}$, and given a set of corresponding marginal productivities, $\mu_{j}$, it is possible to construct an aggregate variable $F$ that combines quantities of different types of inputs into a measure of total quality-adjusted labour or capital input, given by the following expression:

$$
\dot{F}_{t}(\operatorname{adj})=\sum_{j} \bar{v}_{j, t} \cdot \dot{F}_{j, t} \quad \text { where } \bar{v}_{j, t}=\frac{1}{2}\left(v_{j, t}+v_{j, t-1}\right) \text { and } v_{j, t}=\frac{\mu_{j, t} F_{j, t}}{\sum_{i} \mu_{i, t} F_{i, t}}
$$

where the dot over a variable indicates the rate of change expressed as a log difference. Therefore, the growth rate of total factor input $\dot{F}$ is the weighted average of the growth rates of different components (using the so-called Törnqvist index as an approximation to a Divisia index). For growth accounting, aggregating heterogeneous inputs according to this procedure is equivalent to employing a production function with many disaggregated inputs, whose coefficients are the respective partial elasticities of output (for a simple exposition, see Barro, 1998).

To take into account the effect of changes in the composition of the labour input, in Scarpetta et al. (2000) six different types of labour have been considered, based on gender and three different educational levels: below upper-secondary education; upper-secondary education and tertiary education. Relative wages are used to proxy for relative productivity. To the extent that this is a reasonable 
assumption, ${ }^{6}$ the measured labour input controls for changes in the "quality" of the workforce over time. Two additional assumptions have also been made to construct a measure of labour input: $i$ ) workers with different levels of education are assumed to work the same (average) number of hours; and ii) relative wage rates are assumed to be constant over the sample period. Compared with other proxies available in the literature (largely for the United States) this decomposition is rather crude, but it does shed light on the role of compositional changes in labour input consistently for a range of OECD countries, thereby permitting cross-country comparisons.

Akin to this concept of labour input, the proper concept of capital with respect to the production function is given by the flow of services of capital in constant prices. Standard measures of capital (based on aggregation of stocks made up of a moving sum of investment at real acquisition prices) rely on two assumptions: 1) the flow of capital services is a constant proportion of an estimated measure of the capital stock and, thus, the rate of change of capital services over time coincides with the rate of change of the capital stock as estimated by cumulating measurable investment according to assumptions about asset lifetimes, physical depreciation, etc; and 2) the aggregate capital stock is made up of one homogenous type of asset, or alternatively, different assets that generate the same marginal revenues in production.

Alternatively, Jorgenson and Griliches (1967) proposed to compute growth rates of capital service of individual assets given information on investment flows, on the service life and on the profile of wear and tear of an asset. Then they suggested aggregating these different capital assets by their marginal productivities, proxied by user costs. User costs are composed of: $i$ ) the opportunity cost of investing money in financial (or other) assets rather than in a capital good; ii) the physical depreciation, i.e. the loss in efficiency/productivity of the capital asset as it ages; and iii) the (expected) capital gain or loss (change in the real value of the asset unrelated to physical depreciation). These three components are reflected in the following expression, where $q_{j}$ is the asset's acquisition price, $r$ is the real rate of interest, and $d_{j}$ is the asset-specific rate of depreciation. Following the expression in [1] above, the weighting factor for each asset $\mu_{\mathrm{j}}$ is proxied by the user cost as:

$$
\mu_{j, t}=q_{j, t}\left(r_{t}+d_{j, t}-\frac{\Delta q_{j, t+1}^{e}}{q_{j, t}}\right)=q_{j, t}\left(r_{t}+d_{j, t}\right)-\Delta q_{j, t+1}^{e}
$$

The inclusion of the market depreciation $\left(-\Delta q_{j}\right)$ as well as its exact quantification have been debated in the literature. Griliches himself (Griliches, 1987) suggests that only physical depreciation should be considered in the user cost, but not the market depreciation. The choice is in fact model dependent. In a putty-clay vintage model productivity is unchanged during the machine's whole lifetime; therefore, if the lifetime is sufficiently long, the marginal productivity of capital can be approximated by the right-hand side of equation [2] without the market depreciation term. Alternatively, equation [2] can be rationalised through the evolution along the balanced growth path of a putty-putty vintage model with perfect foresight (i.e., $q_{j}^{e}=q_{j}$ ). However, outside the balanced growth path, market depreciation in a putty-putty vintage model should be introduced in equation [2] in expected terms. ${ }^{7}$ In practice, the

6. This assumption, necessary for the quantitative analysis, is common in the literature even if it is certainly rather strong. It implies that firms operate under constant returns to scale in competitive input and product markets and maximise their profits by equating compensation with each worker's contribution to output. BLS (1993) discusses how deviations from these hypotheses affect the relationship between the contribution to output and compensation.

7. It should also be stressed that aggregation through (however defined) user costs assumes that assets are homogeneous. This implies that different vintages of the same machine should be counted as different assets, while their current prices (expressed in terms of the output deflator) appear in equation [1]. In practice, however, this would introduce unsolvable problems in the construction of growth rates for new 
expression proposed by Jorgenson and Griliches (1967), the one more commonly used in the literature, assumes extrapolative expectations, while an expression without market depreciation could be rationalised through myopic expectations.

The capital service measure used here is taken from Schreyer (2000). It is calculated for the G-7 countries on the basis of an aggregation across six types of capital goods weighted with their user costs also considering capital gains or losses and hedonic deflators. Given the great heterogeneity of physical capital assets, this is still a fairly high level of aggregation. As a matter of comparison, Jorgenson generally uses a decomposition of capital into 69 different assets. An important omission in the decomposition used here is that ICT assets do not include software, given data limitations at the international level. Recent studies on the United States (Jorgenson and Stiroh, 2000; and Oliner and Sichel, 2000) incorporate software as an ICT asset and find that it plays an important role. Moreover, a number of assumptions had to be made in computing capital stocks by asset, in deriving user costs expressions and in aggregating across assets. Particular effort was made to derive a set of internationally harmonised price indices (based on hedonic adjustments) for investment in ICT assets. Figure 3 shows the difference between the original price deflator for ICT equipment and the harmonised one for Germany, whose official data do not adjust for quality changes in ICT assets.

\subsection{Evidence on the effects of changes in the composition and quality of labour and capital}

Figure 4 decomposes changes in total labour input into a component that reflects unweighted changes in total hours and a component that reflects the varying educational composition of labour, as well as changes in the relative wages earned by different workers. Given data availability, the decomposition covers only a selected number of OECD countries and the 1985-96 period. Human capital increased in all but one country, implying that quality-adjusted hourly labour input grew faster than total hours. ${ }^{8}$ In most European countries, sluggish employment growth and falling hours worked have been accompanied by a significant up-skilling of the workforce. This suggests that productivity gains have been achieved in part by dismissing or not employing low-productivity workers. In contrast, in the United States, Australia and the Netherlands, skill upgrading has played a relatively modest role in total labour input. Favourable underlying labour market conditions and/or labour market reforms have, most likely, widened the employment base in these countries, especially in the 1990s, allowing low-skilled workers to get a foothold into employment, but possibly reducing the overall process of skill-upgrading. ${ }^{9}$

machines. As a solution, Jorgenson and Griliches (1967) suggest extending the foregoing procedure to aggregate different vintages of the same asset through the use of hedonic price indexes. In this way the aggregate flow of capital services of each asset across all vintages can be seen as proportional to the existing stock of that capital asset expressed in efficiency units.

8. The result for Germany reflects the discrete fall in the average education level of the workforce in the aftermath of the unification with the Eastern Länder.

9. Comparing the variation in education attainment of employment and working age population at large suggests that there has been a general tendency towards skill-biased employment growth insofar as the increase in the share of employed persons with upper-secondary education is higher than the change in the same share within the total working-age population. See Scarpetta et al. (2000) for more details. 
Figure 3. Price indices for ICT equipment

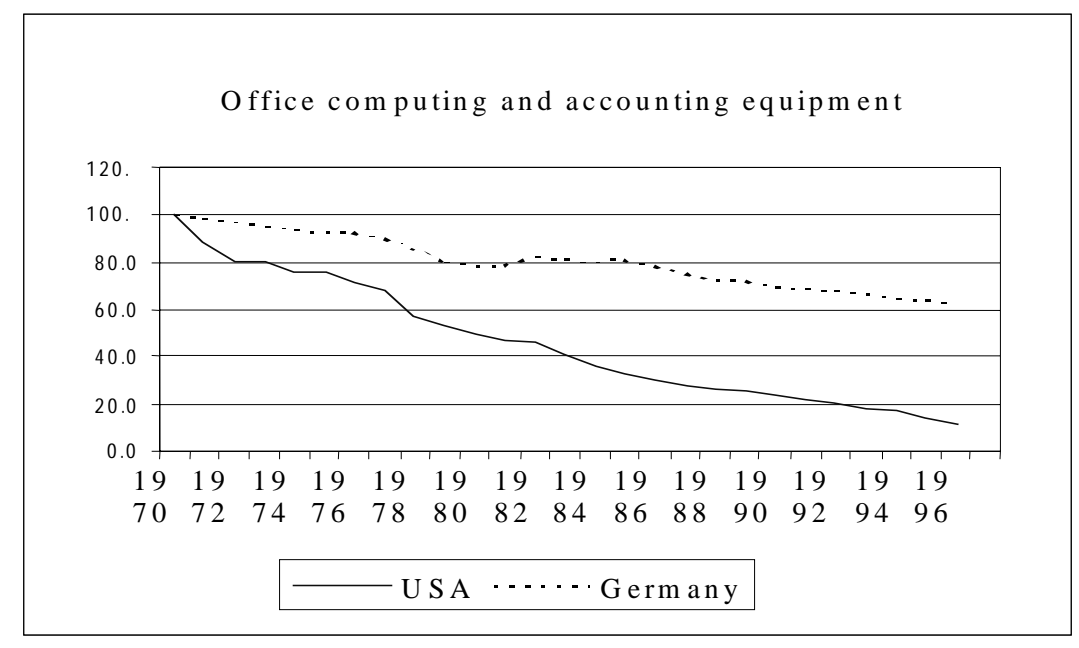

Source: Schreyer (2000).

Turning now to the role that ICT plays in the economy, directly as a producer of final consumption and investment goods, and indirectly via the utilisation of these investment goods in the production process, it should be observed that the contribution of the information and communication technology to output and productivity growth can take three main forms: $i$ ) acceleration of productivity growth in the ICT-producing sectors themselves and an increase of their weight in the economy; ii) capital deepening driven by rapid investment in ICT equipment; and iii) ICT-using sectors enhancing their efficiency by harnessing new technology.

To shed light on the direct contribution of the ICT industry to overall growth in the 1990s, we consider the share of total labour productivity growth of a composite industry comprising the Office and computing machinery industry (ISIC 3825) plus the Radio, TV \& communication equipment industry (ISIC 3823). ${ }^{10}$ In the United States, over the 1990-97 period, this industry enjoyed an annual average labour productivity growth above 10 per cent (compared with a 2.3 per cent annual average in the manufacturing sector) and accounted for about 40 per cent of total manufacturing labour productivity growth. International comparisons of the contribution of ICT industry to manufacturing productivity growth is limited by the fact that some countries, including the United States, use hedonic price deflators for computers and others do not. This is likely to have a significant impact on measured productivity in the industry. ${ }^{11}$ However, available data suggest that, although generally higher than the manufacturing average, labour productivity growth rates of ICT industry have been smaller in most of the other OECD countries (for which data are available) as compared with the United States.

10. The OECD definition of the ICT industry includes "those industries which facilitate, by electronic means, the processing, transmission and display of information”. See http://www.oecd.org/dsti/sti/it/stats/defin.htm.

11. The use of hedonic price deflators tends to boost the contribution of the ICT industry in two ways: $i$ ) it raises its value added compared with that of other industries; and ii) lowers the value added in industries which use ICT products (e.g. semiconductors) as intermediate inputs. 
Figure 4. Effects on labour productivity of adjusting for hours and human capital, 1985-98

Average annual rates of change

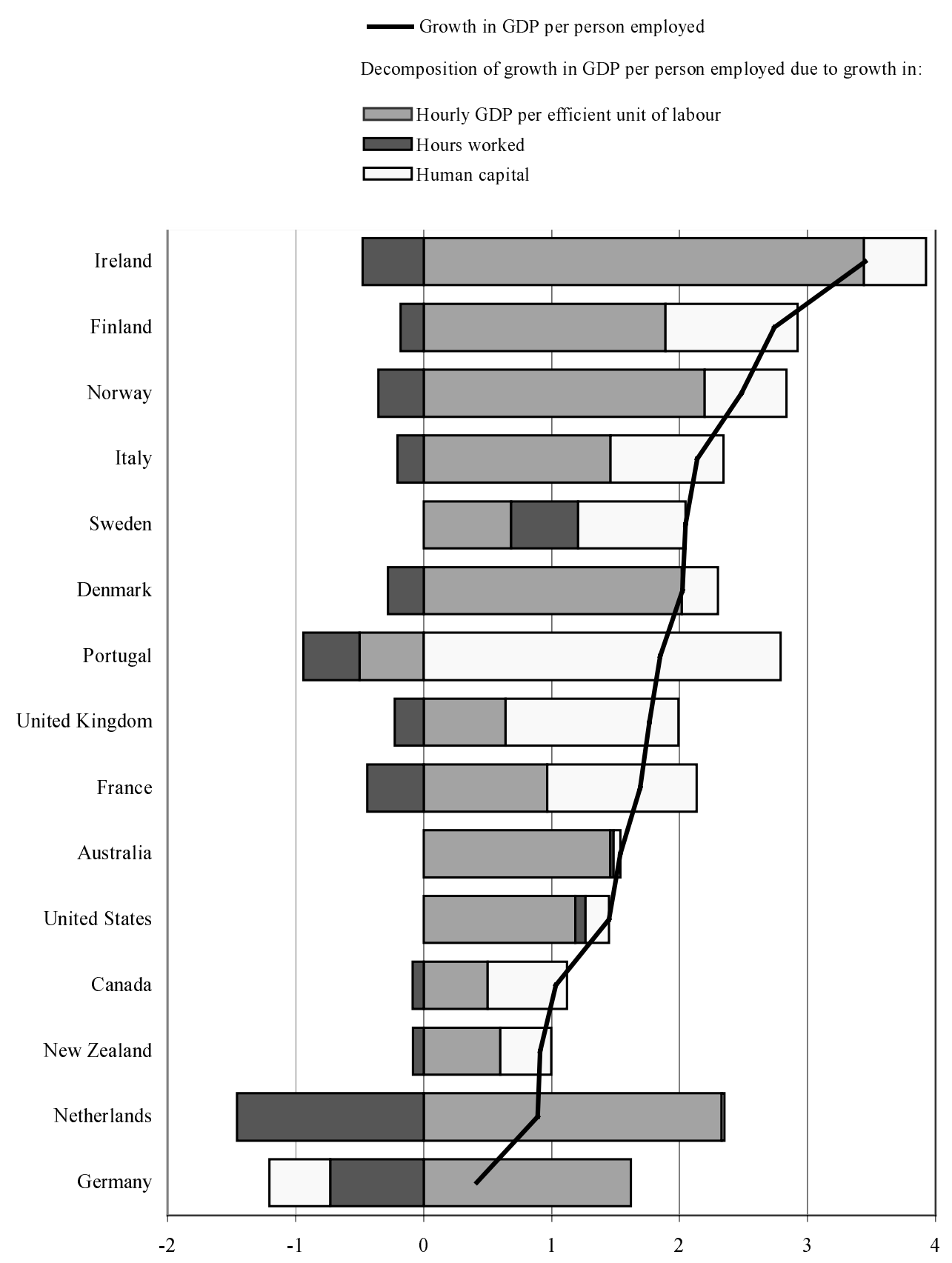

Based on the quantitative decomposition: growth in GDP per person employed $=$

labour productivity adjusted for hours and human capital + growth in average hours worked

+ human capital adjustment.

Source: Scarpetta et al. (2000). 
Table 1 focuses on ICT investment in the G-7 countries. The share of IT capital goods in total investment expenditure rose steadily over the 1990s, and accounted for 5-10 per cent of total nonresidential gross fixed capital formation in the G-7 countries in 1996. The share of communication equipment also rose, though less rapidly, and accounted for around 5 per cent of total non-residential investment. ${ }^{12}$ Moreover, at constant prices volume growth rates of IT capital investment progressed at an annual rate ranging from 11 per cent in France to 24 per cent in the United States in the 1990-96 period. This fast growth is due to an annual decline in IT price indices of about 10 per cent, reflecting rapid quality improvements and technical progress embodied in these capital goods (see below).

Table 1. The evolution of investment in IT

\begin{tabular}{|c|c|c|c|c|c|c|c|}
\hline & Canada & France & $\begin{array}{l}\text { Western } \\
\text { Germany }\end{array}$ & Italy & Japan & $\begin{array}{l}\text { United } \\
\text { Kingdom }\end{array}$ & $\begin{array}{l}\text { United } \\
\text { States }\end{array}$ \\
\hline \multicolumn{8}{|c|}{ Share of IT in non-residential Gross Fixed Capital Formation: } \\
\hline 1990 & 7.3 & 5.0 & 3.5 & 4.1 & 3.8 & 7.5 & 8.7 \\
\hline 1996 & 10.1 & 6.0 & 6.1 & 4.2 & 4.6 & 11.7 & 13.4 \\
\hline \multicolumn{8}{|c|}{ Average annual rate of growth of constant price expenditure on IT: } \\
\hline $1985-90$ & 17.2 & 16.2 & 18.8 & 20.8 & 23.6 & 25.5 & 19.6 \\
\hline $1990-96$ & 17.6 & 11.0 & 18.6 & 12.9 & 14.5 & 17.6 & 23.8 \\
\hline \multicolumn{8}{|l|}{ Harmonised price deflator for IT: } \\
\hline $1985-90$ & -9.4 & -10.2 & -10.3 & -8.1 & -12.0 & -6.7 & -10.4 \\
\hline $1990-96$ & -11.1 & -9.2 & -10.7 & -9.1 & -12.5 & -9.1 & -11.5 \\
\hline \multicolumn{8}{|c|}{ Share of ICT in nominal productive capital stock: } \\
\hline 1985 & 4.3 & 2.4 & 2.9 & 1.3 & 1.2 & 3.6 & 6.2 \\
\hline 1990 & 5.0 & 3.2 & 3.0 & 2.1 & 2.3 & 5.2 & 7.4 \\
\hline
\end{tabular}

The strong pace of investment in ICT has led to a change in the overall composition of capital. ${ }^{13}$ Table 2 presents estimates of this composition effect for the G-7 countries based on comparing inputs of different types of capital weighted together either by acquisition prices or the relevant user costs. Several caveats are called for before interpreting these effects. First, the size of the composition effect depends on the level of detail at which aggregation with user costs or with acquisition prices is available. As said, the present results are based on an aggregation across six types of capital goods - given the great heterogeneity of physical capital assets, this is still a fairly high level of aggregation and so it is likely to under-estimate the compositional effect. Second, a number of assumptions have to be made in the course of computing capital stocks by asset, in deriving user cost expressions and in aggregating across assets. Accordingly, the resulting time series of capital inputs and capital stocks may vary from those available from other sources, including national statistical offices.

12. Methodologies to measure the price change in ICT capital goods vary a great deal across the OECD countries and even the G-7. The figures reported in Table 2 are based on a harmonised deflator constructed on the assumption that the differences between price changes for ICT capital goods and non-ICT goods are the same across countries. See Schreyer (2000) for more details.

13. Schreyer (2000) also calculates the contribution of ICT equipment (basically hardware) to total business sector output growth. He finds that, in the United States, ICT equipment contributed 0.4 percentage points to a total output growth of about 3 per cent (i.e. a 14 per cent contribution) in the 1990-96 period. Oliner and Sichel (2000) find a contribution of 19 per cent in the same period also considering software and communication equipment and, in addition, point out that the contribution rose to 23 per cent in the 1996-99 period. 
The first consideration that emerges from Table 2 is that the rapid investment in information and communication technology assets led to a positive compositional effect, in all G-7 countries, and over both time periods shown, i.e. capital services have grown at a more rapid pace than the capital stock. ${ }^{14}$ ICT assets are relatively short lived and, on the assumptions adopted, their marginal productivity in each of the few periods of their service life has to be high enough to finance depreciation and capital losses. Available evidence suggests that the capital composition effect in the United States is likely to have increased significantly in the past few years due to a marked boost in ICT investment. For example, Oliner and Sichel (2000) suggest that the growth rate in both hardware and communication equipment almost doubled in the 1996-99 period compared with the first half of the 1990s.

\section{Table 2. Capital input and capital composition}

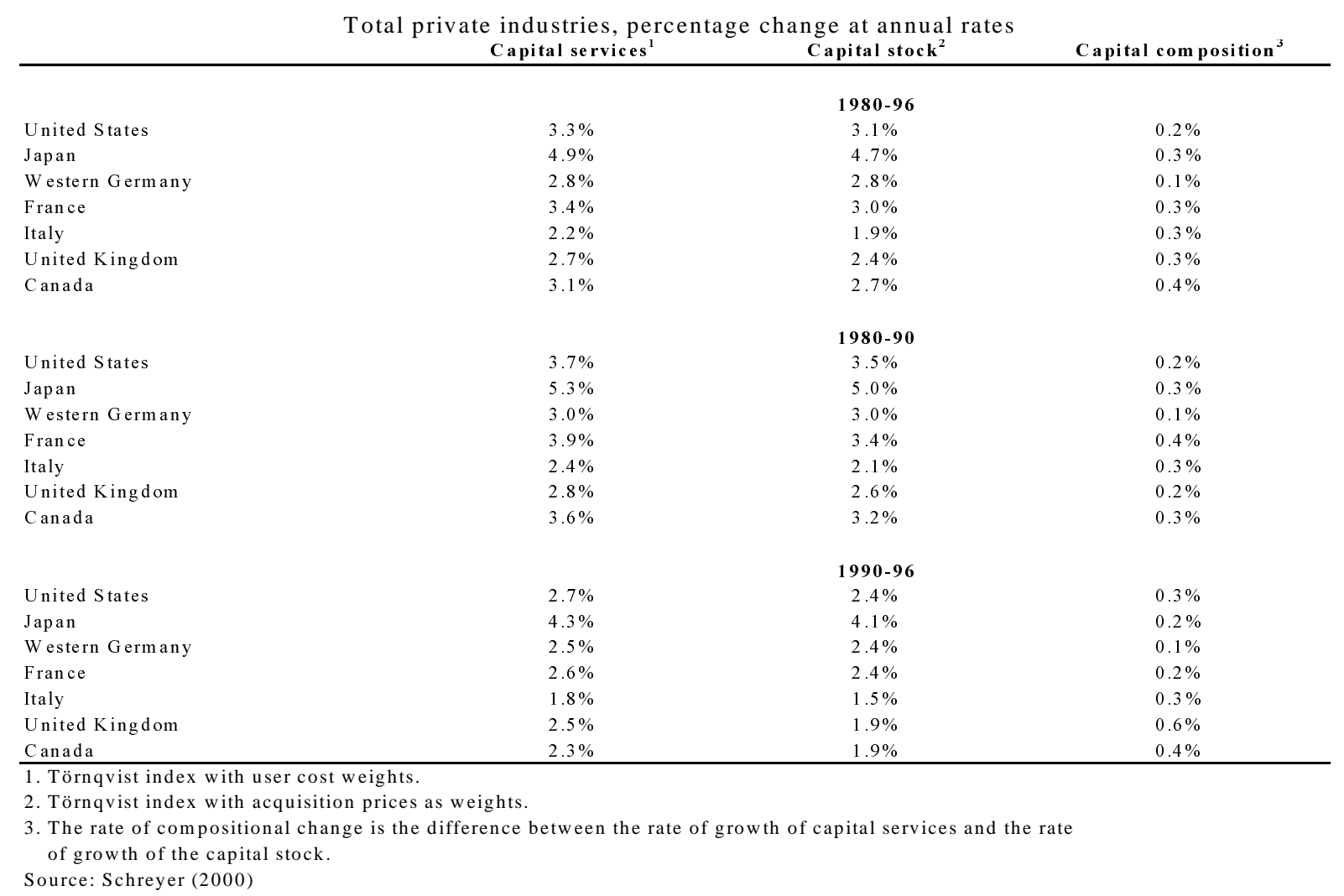

The second point is that the positive quality/composition effect implies a stronger contribution of capital to output growth (at the same time, measured multi-factor productivity growth would decline by the same amount, see below). In other words, the measurement of capital services shifts some of the growth effects from multifactor productivity growth to capital. The importance of this should not be exaggerated: the impact of the compositional change of the capital measure on the contribution of capital to output

14. This reflects a situation where the more rapidly growing assets command a higher share in total user costs than they do in the total capital stock, valued at acquisition prices. This happens when relative acquisition prices between assets are not equal to relative user costs. One important factor that drives a wedge between relative user costs and relative acquisition prices is depreciation: short-lived assets exhibit higher costs of depreciation and user costs than longer-lived assets. Thus, if investment in short-lived assets is more rapid than investment in other assets, an index based on relative user costs will attach more weight to these shortlived assets than an index based on acquisition prices. The higher user cost weights for short-lived assets are appropriate because they approximate more accurately the higher marginal productivity of short-lived assets. 
growth is the product of the overall cost share of capital times the compositional effect. In Table 2 this impact is relatively small and fairly similar across the G-7. For example, assuming an overall cost share of about one-third, the impact on the measured contribution to output growth amounts to about a third of the composition effect, that is to say, 0.1 percentage points (one third of 0.3) in the United States business sector output growth in the period 1990-96.

\section{Estimates of multi-factor productivity and the "embodiment" controversy}

From the discussion of the previous section, it is evident that controlling for quality and compositional changes in labour and capital inputs has an important bearing for our assessment of output and productivity performance. We now turn the attention to measures of multifactor productivity (MFP) and show how adjustments for labour and especially capital may help shedding light on the different sources of technological progress in our international comparison. Our interest is in the impact of changes in broadly defined technology, knowledge and efficiency ("technological change") on output. "Technological change" reflects changes in the "average" technology used by an economy, which in a standard growth model, can keep on improving in the long run only if the technological frontier is also improving.

\subsection{Different measures of MFP growth}

MFP is commonly defined as the portion of output growth left after accounting for growth in capital and labour, where both capital and labour are expressed in quality-adjusted terms. ${ }^{15}$ Arguably, this measure captures disembodied technological and organisational improvements that increase output for given amount of inputs. Dale Jorgenson, in particular, argues that this is the only identifiable component of technological progress. The other procedures to calculate MFP that use different measures for the capital aggregate (e.g. capital stock at acquisition prices) are likely also to pick up changes in the composition and quality of the capital stock due to other reasons than technological change. Consistently, both the Bureau of Labor Statistics (BLS) and many academic researchers do concentrate on this measure of MFP.

Other researchers have recently focused on the identification of the "embodied" part of technological progress. In particular, Greenwood et al. (1997) and Hercowitz (1998) have suggested a way to tackle the "embodiment" controversy by adding an additional source of information (and in fact mixing the primal and dual approach). On the one hand they suggest the estimation of the disembodied component as the residual of a production function where the aggregate flow of capital services is obtained through the user costs aggregation procedure and hedonic prices. On the other hand they suggest computing the growth rate of the embodied component as the growth rate of the inverse of the hedonic deflator of equipment multiplied by its share in value-added. The rationale behind this procedure is that, in a general equilibrium vintage model, ceteris paribus, the fall in the price of existing vintages as they age (mirrored by the hedonic deflator) reflects technological change. ${ }^{16} \mathrm{~A}$ similar procedure would consist in passing thoroughly to the dual (still making use of hedonic deflators) and obtaining overall technological progress as the

15. We leave aside the issue of economies of scale and mark-up pricing (See Morrison, 1999).

16. By using this approach, Greenwood et al. (1997) found that some 60 per cent of post-war productivity growth can be attributed to embodied (or as they termed, investment-specific) technological progress. Moreover, when proper account is made of rapid technological improvement in the production of new capital goods (e.g. computers), the decline in productivity of other factors is strong. Hence, the production of these capital assets and their use play a key role to growth. 
difference between changes in unit costs of output and changes in unit costs of inputs multiplied by their respective share (see e.g. Morrison, 1999). ${ }^{17}$

In the context of our international comparison, we do not have hedonic prices for most countries, and more generally, even when available, hedonic prices refer to a few capital goods. To shed some light on the potentially embodied part of technological progress a simpler route can be followed by recalling the original contribution from Solow (1960). Indeed, if there were only one type of asset with different vintages, we could obtain an aggregate measure of capital input by perpetual inventory and deflation of investment through real acquisition prices (and not hedonic prices). ${ }^{18}$ Then, overall technological change could be computed as the growth of the residual of a production function that employs this measure of capital input. If there are multiple types of assets, the growth rate of each asset can be computed following this procedure (using real acquisition prices), while further capital aggregation can be accomplished using shares in total compensation. Admittedly, biases in the computation of this measure can still appear in the absence of a constant rate of technological change or in the absence of perfect foresight (see Solow, 1960, Nelson, 1964, and Diamond, 1965). ${ }^{19}$ Furthermore, biases in the computation emerge if output is still computed using hedonic deflators. However, these objections apply also to the procedure suggested by Greenwood et al. and the dual approach.

In practice, a consistent use of real acquisition prices as well as of hedonic prices is not everywhere viable, since statistical offices seldom provide either real acquisition prices for all assets or hedonic prices for all assets. However, the argument of the previous paragraph can be led to its extreme. Following Fisher $(1965,1968)$ we can observe that a vintage model is mathematically equivalent to a nonvintage growth model with multiple capital assets characterised by different efficiency. Hence, what appears to be a change in the composition of the aggregate capital stock can well be the effect of the diffusion of technological change. If capital is aggregated through the shares in total compensation of its components (that is, the procedure subsumed in equations [1] and [2]), then this effect is missed in the measure of the productivity residual. This issue can be particularly relevant when, due to the introduction of a new general-purpose technology, the economy undertakes a slow shift towards a new type of capital asset (e.g., ICT).

From the above discussion, we add to the "standard" MFP measure based on quality-adjusted labour and capital, additional measures which are closer in the spirit to the Solow residual and can potentially proxy embodied and disembodied technological progress. More formally, we consider the identity $Y=W L+R_{k} K$, where $Y$ is output, $W$ is the hourly real wage, $L$ is employment (corrected for hours worked), $R_{k}$ is the real return to capital and $K$ is capital. The growth rate of MFP can be derived from the primal or dual residual as follows:

$$
M \dot{F P}=\dot{y}-s_{L} \dot{l}-s_{K} \dot{k}=s_{L} \dot{w}+s_{K} \dot{r}_{k}
$$

17. A problem of the dual approach (and of the methodology proposed by Greenwood et al.) is that price changes can also reflect changes in preferences that might have nothing to do with technological change.

18. Solow indeed showed that his model with homogeneous capital and disembodied technological change (Solow, 1957) is observationally equivalent (in the steady state and with perfect foresight) to his model with vintage capital and embodied technological change (Solow, 1960), provided that capital stock in the latter is "measured by the real market value of the stock of capital" (Solow, 1960, p.100), or, equivalently, in units of foregone consumption.

19. In fact, in the way we measure the growth rate of the average technology, the distribution of different vintages fluctuates in the presence of movements around the steady state. Furthermore, prices would not reflect expected productivities in the absence of perfect foresight. 
where, as before, the dot over a lower-case variable indicates its rate of change expressed as a $\log$ difference; $s_{L}$ and $s_{K}$ denote each factor's share in total compensation. All measures can be identified by redefinitions of prices and quantities in such a way to shift part of the effect captured by the left-hand side to the growth rate of labour and capital. We have already discussed above the compositional effects on labour and capital and concentrate here on how to identify technological progress embodied in capital. Recalling equation [2], $R_{k}$ can be written as:

$$
R_{k}=P_{k}\left(r+d-\dot{p}_{k}\right)
$$

A Solow-type measure of MFP would use acquisition prices for $P_{k}$. A Jorgenson-type measure of MFP uses hedonic prices and shifts the quality effect (as well as the between assets compositional effect) into the growth of the capital stock (writing the growth rate of the capital stock in efficiency units). Let us define the hedonic price index as $Q_{k}=P_{k} / Z$, where $Z$ is embodied technological change (change in the within-asset composition of the capital stock). The rate of change of $Q_{k}$ is equal to the rate of change of $P_{k}$ minus the rate of change of $Z$, which in turn, from equation [4], is approximately equal to to the rate of change of $R_{k}$ minus the rate of change of $Z$. Therefore, abstracting from the between-asset compositional effect, we can write a Jorgenson-type measure of MFP growth as:

$$
M \dot{M F} P_{\text {disemb. }}=\dot{y}-s_{L} \dot{l}-s_{K} \dot{k}-s_{K} \dot{z}=M \dot{F} P_{\text {emb. }+ \text { disem. }}-s_{K} \dot{z}
$$

In those countries where hedonic prices are used to deflate some capital assets (usually ICT), we need to add the "embodied technological change" contained in these assets to obtain a Solow-type measure of MFP. This can be obtained from the growth rate of $Z$, that can be measured as the difference between the growth rate of hedonic prices and that of real acquisition prices, multiplied by the corresponding share of that asset in total compensation. The reverse has to be done, in countries where no hedonic deflator is used, to obtain the Jorgenson-type measure from the Solow-type measure. ${ }^{20}$

To sum up, we consider four measures of MFP obtained through different growth accounting exercises. The first measure proxies fully disembodied technological change and is obtained using labour and capital services adjusted for quality (through hedonic deflators) and composition. The second measure reflects both embodied and disembodied technological change, by using a user-cost aggregation of different capital assets, each evaluated at acquisition prices. The third measure also accounts for the compositional effect on capital, using capital stock aggregated at acquisition prices. The fourth measure extends the third by also including human capital by adjusting labour only for hours worked.

Available data for the United States, presented in Figure 5, allow one to see the effect of moving from a measure of MFP growth to another ${ }^{21}$. The figure suggests a number of considerations. The finer measure of MFP growth rate that controls for human capital and capital composition or quality is lower than the other three that make only partial adjustments, as expected. However, the effect varies over time. The pure compositional effect on capital was generally relatively modest over the past two decades, which, however, may also reflect the limited decomposition of capital assets in our measure of capital service (only 6 assets). Embodied technological progress (in ICT equipment), however, was strong, especially since the mid-1980s, due to the rapid fall in relative prices and a greater role of ICT equipment in the capital stock. By contrast, a significant improvement in human capital took place in the early to mid 1990s in the United States.

20. The difference in growth rates of hedonic and conventional ("matched model") ICT price deflators for the G-7 countries has been obtained using the harmonised ICT price deflators and each country's non-hedonic price deflator (when available) or a benchmark non-hedonic price deflator (that of Western Germany).

21. Measures of MFP that appear in this paper refer to the business sector. 


\title{
Figure 5. Different measures of trend MFP growth rates for the United States, 1981-99
}

\author{
Annual growth rates
}

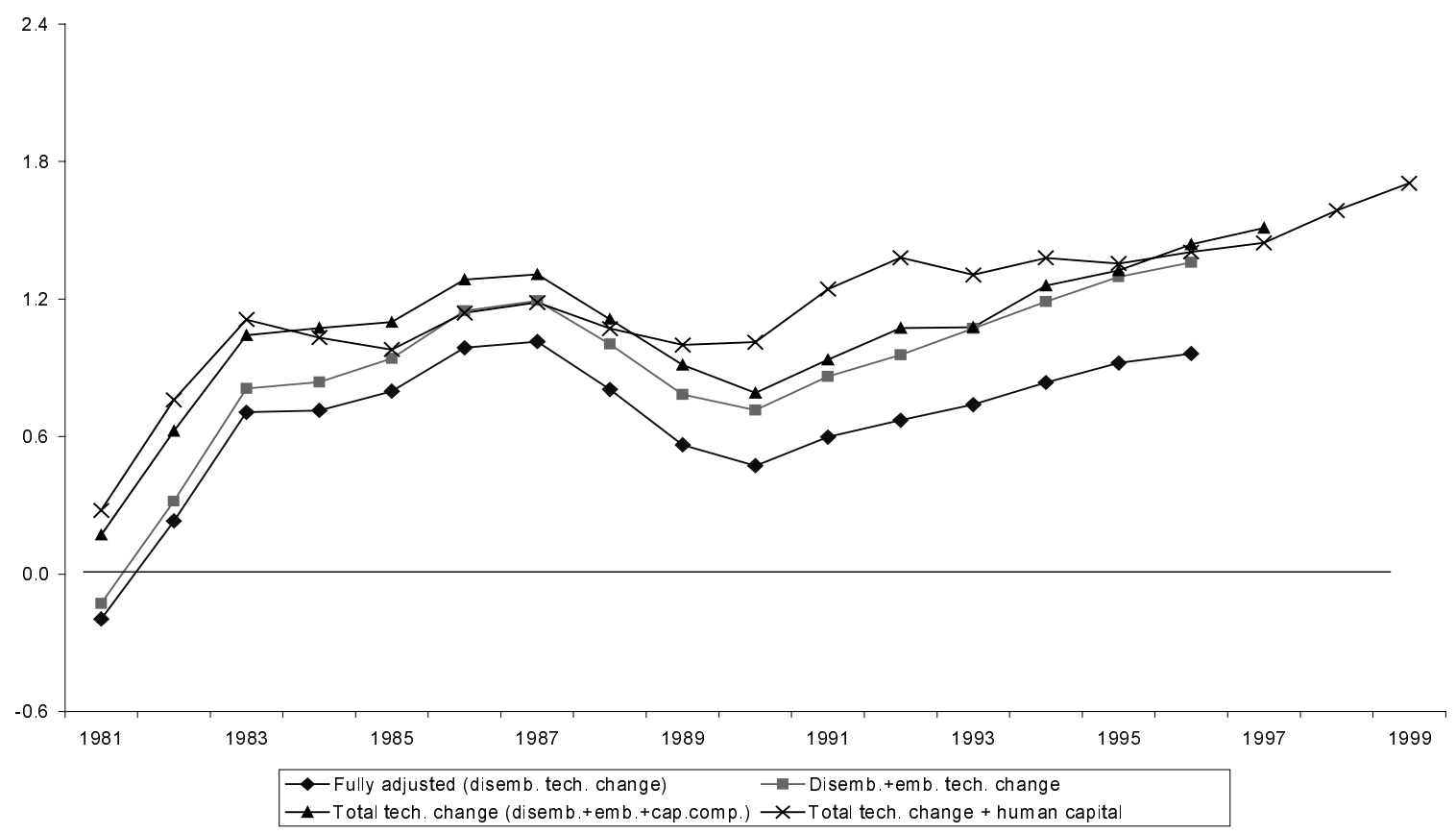

Our data are based on trend series and stop in $1997,{ }^{22}$ both factors limiting the possibility to fully grasp the very recent pick in productivity. Figure 6 indeed suggests that for the most recent years the trend-based measure of MFP is significantly below the actual series. However, the discussion above seems to be consistent with the very recent US studies, even though they somewhat differ in terms of methodologies and data used. ${ }^{23}$ Jorgenson and Stiroh (2000), using data up to 1998 and a sectoral decomposition of MFP, find acceleration in MFP in the computer-producing sector. Moreover, this increase is also visible in the aggregate MFP growth rate to the extent to which the surge in MFP growth in the computer industry is very strong and the size of the industry is getting bigger and bigger. In their study aggregate MFP growth went from 0.7 in the 1980-90 period to 1.2 in the 1995-98. Oliner and Sichel (2000)

22. Except for what concerns the simple measure of MFP based on preliminary estimates for the growth rate of the capital stock in 1998 and 1999.

23. The main problem with the US data is that official revisions on capital services will not be released until mid-2000. BEA released new data on output (1996-based) in October 1999. So different authors took different routes in tackling consistency problems in the data. The calculations of Whelan (2000) are based on the old NIPA (1992-based). The other studies all used revised NIPA (1996-based) for output, but different estimates for capital services. Oliner and Sichel adjusted BLS figures for capital services (1999 release, consistent with 1992-based NIPA) in order to "anticipate" the expected revision by BLS and make capital service figures approximately consistent with the new output figures. CEA (2000) used "preliminary" revised data for capital services. Finally, Jorgenson and Stiroh (2000) used data constructed on the basis of revised figures from the Bureau of Economic Analysis (BEA) for investment and prices until 1997 and made additional estimates for 1998. In this paper we use a concept of gross capital stock and capital services divided in six categories. Data are from Scarpetta et al. (2000), and for the United States they stop in 1997. For 1998 and 1999 gross capital stock series has been extended by regressing the growth rate of gross capital stock on that of BEA's net capital stock over 1994-1997 where both series are available. 
confirm the contribution of the ICT industry to aggregate MFP growth: according to their estimates, about one-third of the 0.75 percentage points increase in MFP growth over the 1996-99 period as compared with the first half of the decade is attributed to the ICT industry. Gordon (2000) claims that the rest of the pickup in MFP is a cyclical phenomenon, as Oliner and Sichel use actual data for output and labour. Oliner and Sichel also calculate the contribution of the utilisation of computer hardware and software to output and labour productivity, that in our calculation, with the exception of software, would be embodied in the broader measure of MFP growth, and suggest that about 50 per cent of the acceleration in labour productivity is due to capital deepening from investment in the ICT sector. Overall they suggest that twothirds of the 1 percentage point pick-up in labour productivity is due to the ICT-producing industry and the utilisation of ICT equipment. Similarly, the Council of Economic Advisors (2000) attributed about 40 per cent of the MFP uptake to the computer industry. Taken together, our measures allow a thorough comparison with these studies. The average growth rate of the simpler measure (hours adjusted only) of MFP growth increases from 0.96 in 1980-90 to 1.36 in 1990-97, and further to 1.59 and 1.70 in the provisional estimates for 1998 and 1999 (see Figure 6). The effect of the recent upswing is obviously reflected more strongly by the computation based on actual series of employment and output. We obtain an average growth rate of 1.47 in 1990-97 that increases further to above 2 per cent in 1998 and 1999, according to our preliminary estimates (see Figure 7).

\section{Figure 6. MFP growth rates in the United States, actual versus trend series, 1965-99}

Annual growth rates

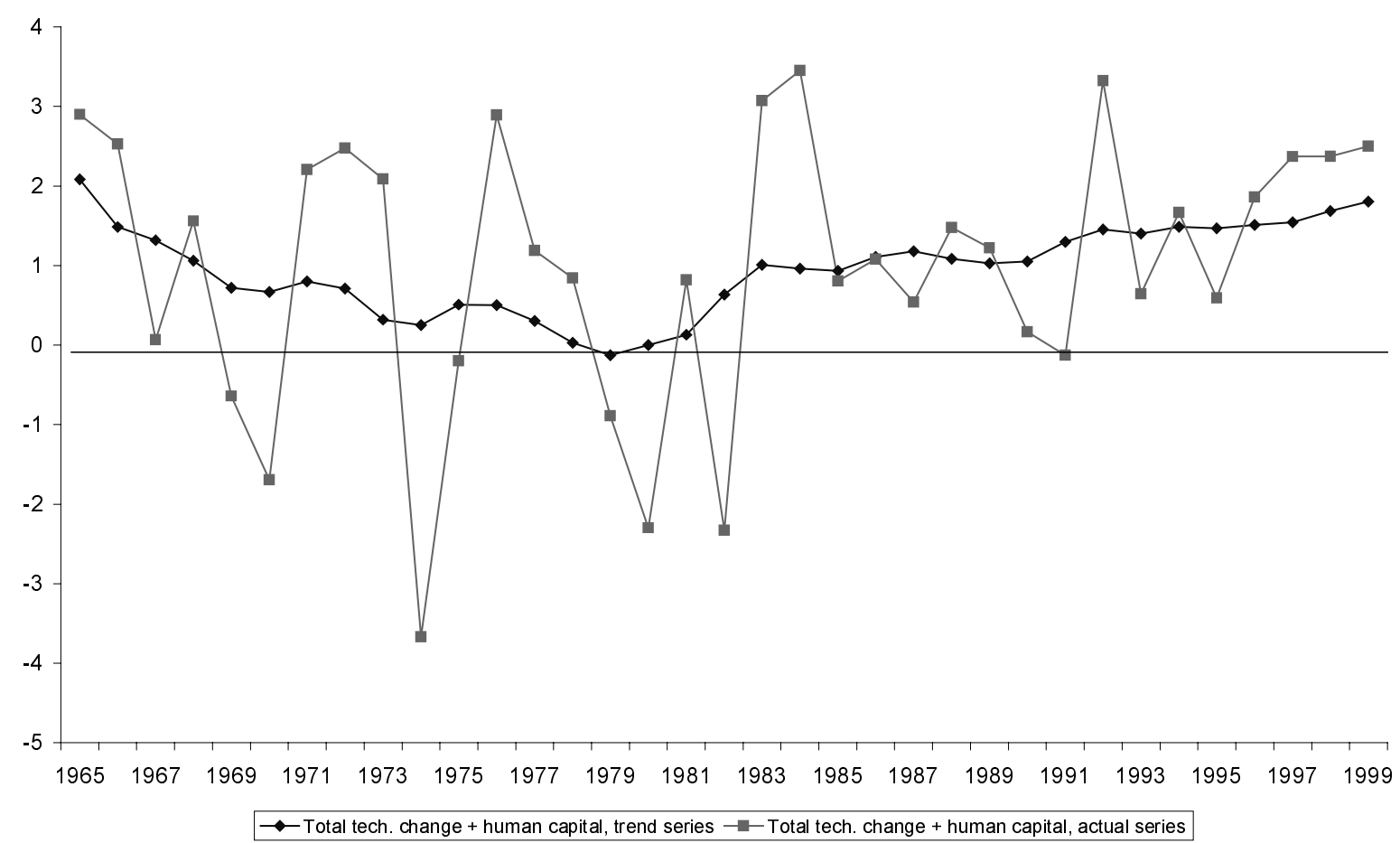

The different elements characterising productivity growth in the United States can be tentatively seen as part of the following story. The end of the productivity slowdown is due to the gradual diffusion of a new (ICT) technology. This technology "revolution" first emerged as purely disembodied MFP growth in the ICT-producing sector but, more recently, it has also emerged in technological progress embodied in new ICT equipment used in many sectors. This new technology also had an impact on the process of human capital formation. In our data, the first wave of adoption of this technology has, indeed, been 
accompanied by a significant shift towards more skilled workers, arguably needed to operate with the new ICT equipment in an efficient way.

Whether ICT is also producing significant spill-over effects and a boost to disembodied technological progress in other sectors of the economy remains more uncertain, partly reflecting measurement uncertainty as well as the difficulty of assessing innovative ICT-based businesses and markets, some of which are at an early stage of development. For example, the network exernalities that may materialise from the spread of the Internet, the Intranet and other networks are likely to become visible once a certain threshold in network use has been passed. In this context, it should be stressed that Internet use has taken off only in the second half of the 1990s and there is anecdotal evidence that this has already produced significant changes in several parts of the economy. Businesses are taking greater advantage of better real-time information systems, rationalising costly precautionary inventory stocks and the distribution of their products. With greater information exchange between customers and producers, companies are likely to reduce labour hoarding that had been required earlier to meet unanticipated increases in product demand. Businesses have also started to reduce costs by integrating their suppliers more closely in the design and manufacturing of products, while also using the Internet to outsource tasks previously carried out internally. Electronic commerce is still in its infancy and unlikely to have had much effect on aggregate productivity to date, but fast expansion in the future could have major effects on distribution efficiency and work to strengthen competition, with beneficial effects on productivity.

Going back to our international comparison means that we miss some of the quality/compositional changes in labour and capital and thus we cannot advance the same type of considerations about the source of technological progress. ${ }^{24}$ Bearing this factor in mind, Table 3 suggests significant variation in MFP growth rates across countries. In most of them, MFP growth was relatively stable, between 0.5 and 2 per cent (annualised) with most measures. A higher growth rate of MFP was registered in Finland and Ireland (above 2 per cent in the 1980s and above 3 per cent in 1990s), while for Switzerland a slightly negative MFP growth rate is estimated over the past decade. Using-quality-adjusted measures of both labour and capital inputs tend to reduce measured MFP.

24. Moreover, for at least Denmark and Sweden, we cannot control for the use of hedonic prices for ICT in the calculation of the crude MFP growth rate. 
ECO/WKP(2000)32

Table 3. Estimates of Multi-Factor Productivity growth rates, 1980-98

Average annual growth rates

( based on trend series time-varying factor shares)

\begin{tabular}{|c|c|c|c|c|c|}
\hline & & $1980^{1}-90$ & $1990^{2}-98^{3}$ & $1995-98^{3}$ & $1990-96^{3}$ \\
\hline \multirow[t]{4}{*}{ United States } & Hours adjusted only & 1.0 & 1.4 & 1.5 & 1.3 \\
\hline & With control for human capital & 1.0 & 1.2 & 1.4 & 1.2 \\
\hline & ... and composition/quality of physical capital & 0.6 &.. &.. & 0.8 \\
\hline & Memo item: Embodiment in IT & 0.2 & 0.3 & 0.4 & 0.3 \\
\hline \multirow[t]{4}{*}{ Japan } & Hours adjusted only & 2.0 & 1.6 & 1.6 & 1.5 \\
\hline & With control for human capital &.. & .. &.. &.. \\
\hline & ... and composition/quality of physical capital & .. &.. & .. &.. \\
\hline & Memo item: Embodiment in IT & 0.1 & 0.1 & 0.2 & 0.1 \\
\hline \multirow[t]{4}{*}{ Germany ${ }^{4}$} & Hours adjusted only & 1.6 & 1.4 & 1.5 & 1.4 \\
\hline & With control for human capital & 1.6 & 1.9 & 1.3 & 2.0 \\
\hline & ... and composition/quality of physical capital & 1.5 & .. & .. & .. \\
\hline & Memo item: Embodiment in IT & 0.1 & .. & .. & .. \\
\hline \multirow[t]{4}{*}{ France } & Hours adjusted only & 2.1 & 1.1 & 1.1 & 1.1 \\
\hline & With control for human capital & 1.9 & 0.7 & 1.0 & 0.5 \\
\hline & ... and composition/quality of physical capital & 1.5 & .. & .. & 0.4 \\
\hline & Memo item: Embodiment in IT & 0.1 & 0.1 & 0.1 & 0.1 \\
\hline \multirow[t]{4}{*}{ Italy } & Hours adjusted only & 1.5 & 1.2 & 1.0 & 1.2 \\
\hline & With control for human capital & 1.4 & 0.6 & 0.7 & 0.5 \\
\hline & ... and composition/quality of physical capital & 1.3 & .. & .. & 0.4 \\
\hline & Memo item: Embodiment in IT & 0.1 & 0.1 & 0.1 & 0.1 \\
\hline \multirow[t]{4}{*}{ United Kingdom } & Hours adjusted only & .. & 1.3 & 1.4 & 1.3 \\
\hline & With control for human capital & .. & 0.5 & 1.2 & 0.5 \\
\hline & ... and composition/quality of physical capital & .. & .. &.. & 0.3 \\
\hline & Memo item: Embodiment in IT & .. & 0.2 & 0.3 & 0.2 \\
\hline \multirow[t]{4}{*}{ Canada } & Hours adjusted only & 0.5 & 1.1 & 1.1 & 1.1 \\
\hline & With control for human capital & 0.4 & 0.9 & 1.0 & 0.8 \\
\hline & ... and composition/quality of physical capital & 0.2 & .. &.. & 0.4 \\
\hline & Memo item: Embodiment in IT & 0.1 & 0.3 & 0.3 & 0.3 \\
\hline
\end{tabular}


Table 3. Estimates of Multi-Factor Productivity growth rates, 1980-98 (continued)

Average annual growth rates

( based on trend series time-varying factor shares)

\begin{tabular}{|c|c|c|c|c|}
\hline & & $1980^{1}-90$ & $1990-98^{3}$ & $1995-98^{3}$ \\
\hline \multirow[t]{2}{*}{ Australia } & Hours adjusted only & 0.9 & 2.1 & 2.1 \\
\hline & With control for human capital & 0.9 & 2.0 & 2.0 \\
\hline \multirow[t]{2}{*}{ Austria } & Hours adjusted only & 1.2 & 1.1 & 1.4 \\
\hline & With control for human capital & .. & .. & .. \\
\hline \multirow[t]{2}{*}{ Belgium } & Hours adjusted only & 1.4 & 1.0 & 0.8 \\
\hline & With control for human capital & .. & .. & .. \\
\hline \multirow[t]{2}{*}{ Denmark } & Hours adjusted only & 1.0 & 1.8 & 1.7 \\
\hline & With control for human capital & 0.9 & 1.9 & 1.6 \\
\hline \multirow[t]{2}{*}{ Finland } & Hours adjusted only & 2.4 & 3.2 & 3.5 \\
\hline & With control for human capital & 2.2 & 2.8 & 3.1 \\
\hline \multirow[t]{2}{*}{ Greece } & Hours adjusted only & 0.6 & 0.3 & 0.6 \\
\hline & With control for human capital & .. & .. & .. \\
\hline \multirow[t]{2}{*}{ Ireland } & Hours adjusted only & 3.9 & 3.9 & 3.6 \\
\hline & With control for human capital & 3.8 & 3.6 & 2.7 \\
\hline \multirow[t]{2}{*}{ Netherlands } & Hours adjusted only & 2.2 & 1.7 & 1.2 \\
\hline & With control for human capital & 2.2 & 1.7 & 1.2 \\
\hline \multirow[t]{2}{*}{ New Zealand } & Hours adjusted only & 0.7 & 1.1 & .. \\
\hline & With control for human capital & 0.6 & 1.2 & .. \\
\hline \multirow[t]{2}{*}{ Norway $^{5}$} & Hours adjusted only & 1.1 & 2.1 & 1.8 \\
\hline & With control for human capital & 0.9 & 1.9 & .. \\
\hline \multirow[t]{2}{*}{ Portugal } & Hours adjusted only & 1.9 & 2.2 & .. \\
\hline & With control for human capital & 1.9 & .. & .. \\
\hline \multirow[t]{2}{*}{ Spain } & Hours adjusted only & 2.2 & 0.6 & 0.4 \\
\hline & With control for human capital & .. & .. & .. \\
\hline \multirow[t]{2}{*}{ Sweden } & Hours adjusted only & 0.8 & 1.3 & 1.3 \\
\hline & With control for human capital & 0.6 & 1.0 & 1.2 \\
\hline \multirow[t]{2}{*}{ Switzerland } & Hours adjusted only & .. & 0.2 & 0.2 \\
\hline & With control for human capital & .. & 0.2 & .. \\
\hline
\end{tabular}

1. 1984 for Denmark, 1986 for New Zealand and Portugal.

2. 1991 for Germany.

3. 1997 for Australia, Belgium, Italy, Norway, Spain and United States, 1996 for Austria, Finland, Greece, Ireland, New Zealand, Sweden and United Kingdom, 1995 for Switzerland, 1992 Portugal.

4. Western Germany before 1991.

5. Mainland only.

Source: OECD.

In a few countries, MFP growth rate unambiguously and significantly increased in the $1990 \mathrm{~s}$ compared with the previous decade. Australia, Canada, Denmark, Finland, Norway and Sweden all experienced an increase in their average growth rates of MFP of at least 0.5 percentage points (in most 
cases from relatively low levels in the 1980s). ${ }^{25}$ The underlying forces behind these positive trends are, however, different and need to be spelled out. In the case of Australia, Denmark and Norway, improvements in the growth rate of MFP have gone hand in hand with high and often rising labour utilisation and rapid GDP per capita growth. In contrast, in Sweden and especially in Finland, increases in MFP growth rates have been accompanied by a significant slow down in GDP per capita growth rates and significant falls in employment rates. In these latter cases, the severe crisis of the early 1990s (in Finland largely due to the collapse of the Soviet market) most likely led to a cleansing of the least productive activities with major employment losses but also with an increase in the recorded average multi-factor productivity. In other countries, including France, Italy, and Spain, trend MFP growth rates decreased significantly. In Italy a sharp decrease in the MFP growth rate emerges only after the quality of labour is taken into account.

\subsection{MFP growth and $R \& D$}

The evidence presented in the previous section suggests that something is changing in productivity growth of a few OECD countries, and most prominently of the United States. This "something" seems to be related to the ICT-producing industry, at least in the United States. But, more recently, the penetration of information and communication technology in the production process of other sectors is boosting their output as well. In this context, ICT is in itself the result of a continuous innovation process, but also offers a tool for further innovation in the production processes of other sectors. To shed light on the relationship between innovation, diffusion of innovation and growth, we look at the relationship between MFP growth and R\&D (see also OECD, 2000), consistently with most of the new growth theory. ${ }^{26}$ Although a measure of MFP that controls for human capital would be more appropriate in this context, we use the cruder measure (due to data availability).

The empirical evidence is generally supportive of a positive and strong relationship between $\mathrm{R} \& \mathrm{D}$ and output or productivity growth, especially when the analysis is conducted at the sectoral or firm levels. ${ }^{27}$ In aggregate cross-country regressions, it is often difficult to establish a clear link between an indicator of $\mathrm{R} \& \mathrm{D}$ effort and productivity growth. ${ }^{28}$ One of the problems is the difficulty in comparing

25. Germany and New Zealand also had somewhat higher MFP growth rates based on input quality adjusted measures in the 1990s compared with the 1980s, although in both cases reversion to the mean can be observed in the most recent years. It should be stressed, however, that in the case of Germany quality adjusted measures are somewhat less reliable because reunification implied a slump in input quality at the beginning of the 1990s that was subsequently recovered, without changes of equal magnitude on output.

26. Two measures of the effectiveness of R\&D are commonly used: the output elasticity of the R\&D stock, and the rate of return to $R \& D$ investment. Both measures are usually based on a Cobb-Douglas production function that includes the $R \& D$ capital stock (or, more often, R\&D intensity) as a separable factor of production. This is equivalent to saying that R\&D can be used as an explanatory variable of MFP. See, amongst many others, Romer (1990), Aghion and Howitt (1998), Barro (1998) and, ante litteram, Nelson and Winter (1982).

27. As summarised by Nadiri (1993), the output elasticities of R\&D at the firm level tend to be around 0.1 to 0.3 and the rates of return around 20 per cent to 30 per cent. At the industry level, elasticities have roughly the same range, while the rates of return are estimated to be between 20 per cent to 40 per cent. Evidence also suggests that basic research has higher returns than applied R\&D (Griliches, 1986) and that process $\mathrm{R} \& \mathrm{D}$ has higher returns than product $\mathrm{R} \& \mathrm{D}$. There is also evidence that the role of $\mathrm{R} \& \mathrm{D}$ may differ between small and large economies. In large countries, $R \& D$ mainly helps to increase the rate of innovation, while in smaller countries, $R \& D$ primarily serves to facilitate the transfer of technology from abroad.

28. In the cross-section of OECD countries, the simple correlation of GERD (Gross Expenditure in R\&D) intensity and MFP growth is around -0.01 in both the 1980s and the 1990s, while the correlation between 
levels of MFP growth across countries, given the differences in the way the capital stock is measured. ${ }^{29}$ Bearing in mind the limitation of bivariate correlation and measurement issues, Figure 7 shows a correlation between changes in business enterprise expenditure in R\&D (BERD) intensity and acceleration in MFP growth. ${ }^{30}$

\section{Figure 7. Changes in MFP growth and change in business R\&D intensity}

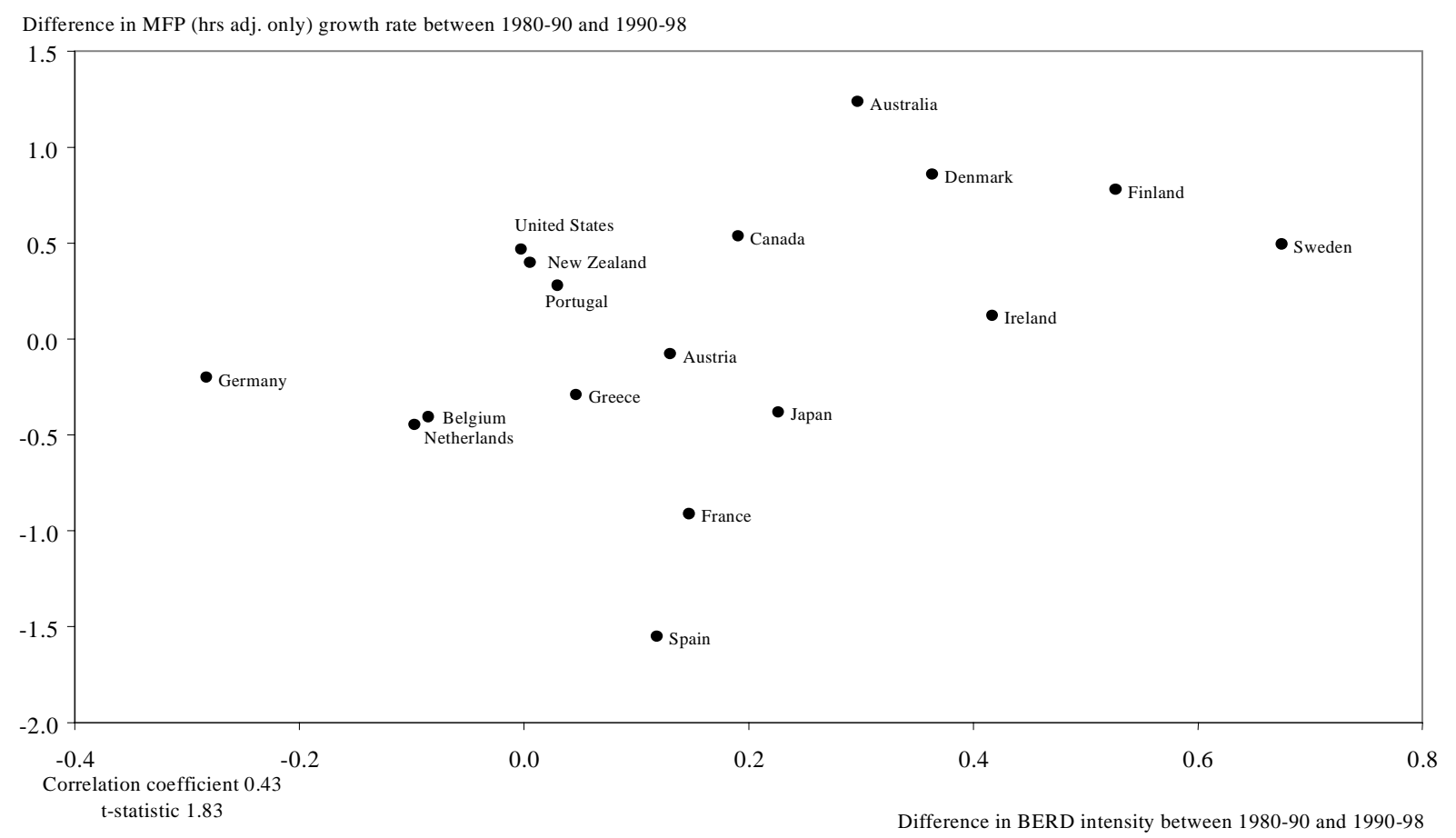

Source: R\&D data are from the OECD MSTI database.

These correlations can be read in two different (although not mutually exclusive) ways. The evidence of a stronger relationship between changes in MFP growth and changes in R\&D intensity than between the former and the level of R\&D intensity may be simply due to measurement problems in different countries which makes first differences more reliable than level values. Alternatively, this evidence may be related to a real economic phenomenon, whereby $R \& D$ plays a specific role in the recovery from the productivity slowdown. The latter interpretation would be consistent with another piece of evidence that might suggest that the mutual link between R\&D and MFP is becoming stronger, not only in the United States. In the OECD countries, the cross-country correlation between growth rates of average BERD and MFP moved from 0.30 (t-statistic equal to 1.22) in the 1980s to 0.79 (t-statistic equal to 5.53) in 1990-98.

BERD (Business Enterprise Expenditure in R\&D) intensity and MFP growth is -0.03 in the 1980s and 0.03 in the $1990 \mathrm{~s}$.

29. See OECD (1998) for a detailed discussion of factors limiting the use of aggregate data to establish a relationship between R\&D and output (or MFP) growth.

30. As shown in the extended version of this study (see Bassanini et al., 2000), there is also some correlation between overall R\&D expenditure intensity (public and private) - i.e. gross expenditure in R\&D (GERD) - and MFP acceleration. An even stronger correlation can be found between changes in the share of BERD in total R\&D and changes in MFP growth. 


\subsection{Does theory help us to explain the productivity slowdown and recovery?}

As computers have been widely used since at least the early seventies, the additional question we should try to address is how to explain the productivity slowdown which has followed the early days of the computer era (the so-called productivity paradox) as well as the very recent productivity recovery. It may be worth recalling, as Paul David properly pointed out (David, 1991), that this is not the first time economists were surprised by the apparent failure of a new technology to show up in higher productivity growth.

Economic theory does provide some hints into the non-linear relation between new technologies and productivity growth. In particular, David $(1990,1991)$ suggests that the diffusion of technology and the development of related institutions and human capital involve a lot of trial-and-error, learning-by-doing and self-reinforcing co-ordination failures which lead to a non-linear relationship between the beginning of the economic exploitation of a general-purpose technology, its pattern of diffusion and the effects on aggregate productivity growth. David's idea has loomed large in the literature. ${ }^{31}$ Greenwood and Jovanovic (1999) are perhaps the most complete example. They combine learning-by-doing and slow diffusion in a putty-putty vintage model where new plants are the carrier of the new technology but entry involves the sunk cost of building a new plant. In their model the productivity slowdown emerges because of: $i$ ) the loss of efficiency due to technology adoption, and ii) the loss of resources due to the establishment of new plants. Conversely, the slow recovery is the outcome of: $i$ ) the steepness of the learning curve, ii) the slowness of aggregate replacement of old vintages (that in turn depends on efficiency loss and sunk costs in establishing a new plant), and iii) second mover advantages that prompt firms to delay entry (along the lines of Silverberg et al., 1988, and Jovanovic and Lach, 1989). Calibration exercises on the US economy undertaken by Greenwood and Jovanovic show that a similar model can produce a prolonged slowdown lasting over 30 years.

In addition to this literature, the Schumpeterian new growth tradition points out that the introduction of a new general purpose technology might generate an outburst of R\&D activity that, drawing resources out of directly productive activities, might generate a temporary reduction in output growth $^{32}$. We can generalise this statement, by noticing that if there are dynamic increasing returns to each general purpose technology, dividing the resources for innovation between many of them would reduce the pace of technological change. The essence of this argument can be illustrated with a two-technology economy (say: old and new), where technological change $g$ is specific to each technology. Aggregate technological change can be written as a weighted average of technological change in each technology:

$$
g=(1-\theta) g_{\text {old }}+\theta g_{\text {new }}
$$

where $\theta$ is the share of output produced with the new technology. Assume that each technology's productivity growth depends on how intensively that technology is used or on how many resources are employed to improve it. Then, technological progress in each technology would be an increasing function of the share of that technology in aggregate capital stock, output, or R\&D expenditure. Therefore total technological change can be written as:

$$
g=(1-\theta) \varphi_{\text {old }}(1-\theta)+\theta \varphi_{\text {new }}(\theta) \text { with } \varphi_{i}>0, d \varphi_{i}(x) / d x>0, i=\text { old,new } .
$$

Notice that there are dynamic increasing returns to each technology. Hence, $g$ is at a maximum when $\theta$ is at the boundary of the interval $[0,1]$. If $\varphi_{i}$ are homogeneous functions of some positive degree, then, as $\theta$

31. See in particular Yorukoglu (1998).

32. See Aghion and Howitt (1998). 
increases, initially $g$ decreases until it reaches a minimum before increasing again. Thus, during the transition from one technological paradigm to another, the aggregate rate of technological progress is bound to slow down, because less resources are invested to improve the old technology while resources invested to improve the new technology are insufficient to compensate. ${ }^{33}$

The bottom line is that recent evidence on productivity trends is consistent with a class of appealing theoretical models of innovation, diffusion and economic growth. Up until recently, these models were largely used to justify the ICT-related productivity paradox, but now can be seen as useful tools to also characterise the recent observed pick-up in disembodied, but especially, embodied technological progress, at least in the United States. As a simple illustration, the productivity slowdown occurred in the early phases of the IC technology and the observed stabilisation and subsequent recovery have occurred once this technology spread to other production processes. It should also be noticed that the trend series in Figure 6 suggest that the US productivity started to recover at the beginning of the 1980s, rather than much later as often pointed out by looking at averages of actual data.

\section{Some policy considerations with reference to framework conditions}

The evidence presented above suggests that some "traditional" factors lay behind differences in growth performance across the OECD countries as well as some new factors, largely related to the diffusion of ICT. These two sets of explanations are not independent of each other but may point to different areas of policy intervention.

Amongst the traditional factors is the very different capacity of countries to employ people of working age. Although wide disparities in employment rates may partly depend upon different social and cultural habits, it is fairly clear that employment patterns over the past two decades are closely related to different policy settings and institutions. It is, in particular, interesting to notice that, among the major countries, the United States experienced improving growth performances in the 1990s in a context of continuously favourable product and labour market conditions. Moreover, the strong employment content of GDP growth in Australia, Canada, Ireland and the Netherlands went hand-in-hand with major product and labour market reforms there, while in Norway ${ }^{34}$ growth was related to persistently favourable labour market conditions over the 1990s (see OECD, 1999). These countries have all experienced significant improvements in labour market performance over the 1990s. In other words, structural changes seem to have led to higher utilisation of labour in a context of more productive use of factor inputs.

On the other side of the spectrum, stagnant employment conditions are often found in countries that have been more hesitant in embarking on bold structural reforms (e.g. several countries in Continental Europe) or in those with economic stagnation - and consequent labour shedding (e.g. Japan). This is also supported by evidence at the sector level, which shows that increase in labour productivity and skill-biased employment adjustment has been associated with net employment losses in Continental Europe. These results seem to be consistent with patterns observed at the firm levels. According to OECD (1998a), productivity growth is almost equally due to successful upsizers (i.e. increasing labour productivity combined with rising employment) and successful downsizers (i.e. increasing labour productivity combined with falling employment) in the United States, Japan and the Netherlands, but not in France where successful downsizers dominated in explaining increases in labour productivity in manufacturing. While at the firm level, the association of labour productivity with changes in employment depends upon demand conditions, returns to scale and technological innovation, it is more difficult to use these concepts

33. Bassanini (1999) develops a fully-fledged model along this intuition.

34. Norway's performance, however, is mostly explained by the performance of the offshore oil industry and its effect on the rest of the economy. 
to explain observed country patterns at the aggregate and manufacturing levels. Relative wage rigidities, regulatory constraints and product market competition conditions are likely to be behind poor employment performance in a number of European countries. ${ }^{35}$

Let us turn to framework conditions for the diffusion of new technologies, and in particular ICT. Both theory and available evidence suggest that the vehicle for the penetration of new general purpose technologies are mainly new firms or old firms with new management and organisation (Hobjin and Jovanovic, 1999). Opportunity costs of switching from old to new technologies are in fact higher for incumbents than for entrants (for a simple albeit formal exposition, see Jovanovic and Nyarko, 1996). Similarly, Gort (1969) argued that another important diffusion mechanism of radically new technologies is through mergers and hostile takeovers that, by substituting new for old managers, rearrange comparative advantages. $^{36}$

Effectively undergoing the transition between economic systems based on different general-purpose technologies implies re-allocating resources to new firms and new activities. As we have seen, the speed at which an economy can undergo this shift of resources has a bearing on the extent and duration of the productivity slowdown. Recalling equation [7] above, the longer an economy is trapped in the middle of the transition, the lower it can benefit from the dynamic increasing returns associated to each technology. Re-allocating resources means primarily allocating financial capital to new firms and activities at the cost of that allocated to declining activities. Financial institutions may be reluctant to finance innovative activities and firms because of the great risk involved as well as monitoring problems. This is particularly true in the case of small firms and start-ups, as these have no or little collateral - as well as retained profits - and are subject to higher risk (Nelson and Winter, 1982, Fazzari et al., 1988). Hence, there is a need to design financial systems that are not solely geared towards the accumulation of physical assets in large, stable firms, in well-established industries (see OECD, 2000).

Venture capital markets effectively combine the financing, management and nurturing of risky projects. They are however unequally developed across the OECD area. Venture capital has developed rapidly in the United States, with some diffusion in Canada and to a lesser extent the United Kingdom. However, since 1995, venture capital investment has expanded rapidly in most European countries (Figure 8), partially following the implementation of policies designed to ease access to venture capital (particularly in Germany, France, Austria, Belgium, Mexico and Sweden). However, important reforms concerning venture capital markets in some countries (e.g. Japan) do not seem to have produced the desired outcome yet. Nevertheless, the role of venture capital should not be over-emphasised and should be seen in the broader context of the financial system characterising each country.

35. The effects of rigidities in the product and labour markets on employment performances are extensively reviewed in the Jobs Strategy publications of the OECD. See in particular OECD (1999) for a detailed overview of policy reforms and employment performance: the study suggests that there has been a close correlation between the effort of reform along the lines of the OECD Jobs Strategy and employment performances in the business sector.

36. Hobjin and Jovanovic (1999) document existing evidence on the rise of entry, exit, takeovers and mergers during the 1970s and early 1980s. For instance, 1972 incumbents in NYSE, AMEX or NASDAQ, suffered much higher erosion of market shares with respect to previous vintages at comparable age. Similarly, stock-prices of small companies surged in the second half of the 1970s and first half of the 1980s vis-à-vis those of large companies, to stabilise thereafter. Finally the rate of capital destruction doubled between 1970 and 1980, to stabilise thereafter, in spite of relatively steady growing rates of capital creation. 
Figure 8. Venture capital investment in early stages and expansion as a percentage of GDP, 1995 and 1998

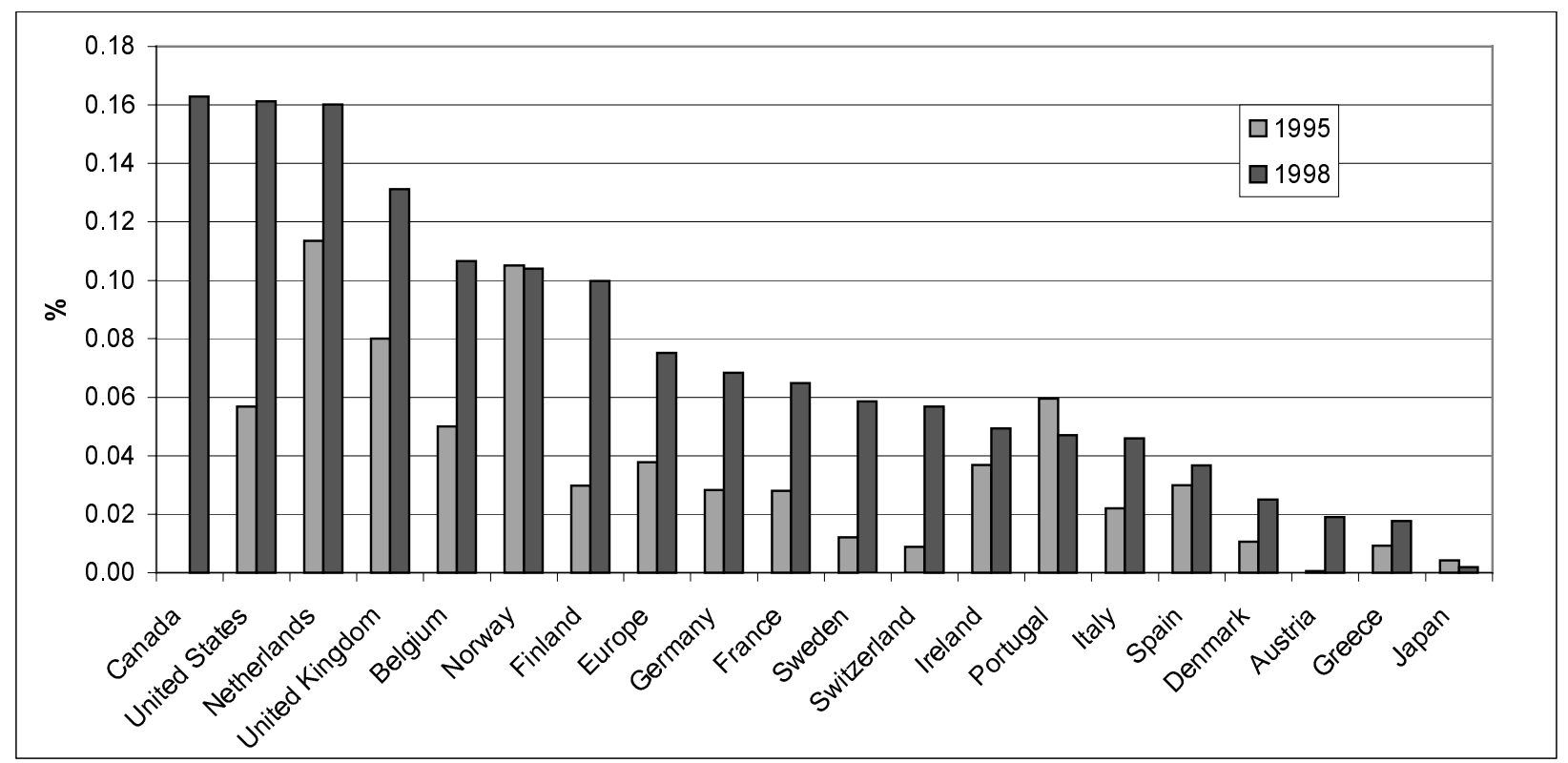

Source: OECD (2000).

The most important role for policy in this context is to provide a framework that enables entrepreneurship to flourish. Conditions in this area vary markedly across OECD countries. Access to financing can be one of the most important barriers. However, other barriers are likely to be important. Excessive regulation in the registration of new businesses (as well as opacity in the procedures) adds further costs that can discourage entry. In this context, estimates suggest that the number of days required to complete a new business vary from 1-2 working weeks in the United States, the United Kingdom and Sweden, to several months in Spain and Italy. Furthermore, administrative procedures might require many steps and a multitude of different agencies. Tentative evidence of the potential impact of cumbersome administrative regulations on productivity performance is shown in Figure 9 on a cross-country basis (the indicator of administrative regulation, as well as all other indicators of regulation, increases with the strictness of regulations). Indeed, strict regulations seem to be associated, ceteris paribus, with poorer MFP growth in the 1990s. ${ }^{37}$

There are a number of other aspects of policy and institutions that may affect firm turnover, innovation and diffusion of innovation. For example, excessive or strongly distortive taxation is detrimental to entrepreneurship. Moreover, the legal framework in which firms operate, e.g. company and bankruptcy laws, have to be geared towards encouraging entrepreneurial activities while also guaranteeing the interests of investors. In the context of the ICT "revolution" and, in particular, the development of e-commerce and more generally Internet-related activities, financial systems have often been called on as key players for the development of new, innovative enterprises. Often limited cash-flow, the lack of collateral and the generally high risk of new, innovative ICT enterprises may point to the importance of

37. The indicator is derived from factor analysis of detailed indicators on a) economy-wide administrative burdens on start-ups of corporate and sole-proprietor firms; $b$ ) industry-specific administrative burdens on start-ups of retail distribution and road freight companies; $c$ ) the features of the licensing and permit system; and $d$ ) the communication and simplicity of rules and procedures (for more details, see Nicoletti et al., 1999). 
equity as a source of finance rather than debt. In this context, the success of venture capital in stimulating the ICT industry in the United States have motivated other countries to develop venture finance

\section{Figure 9. Changes in MFP growth, administrative regulation} and labour protection legislation

Panel A: Administrative regulation

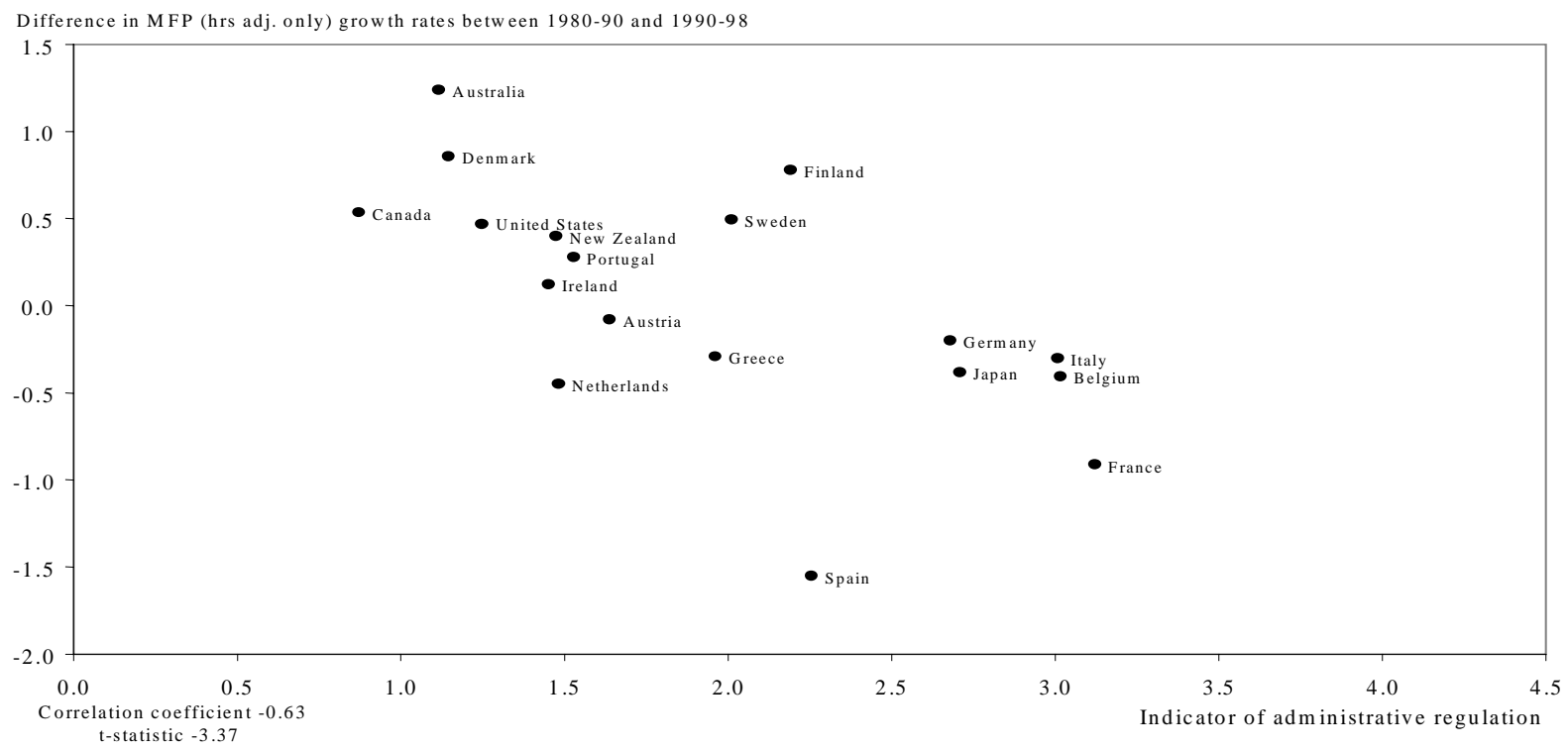

Panel B: Employment protection legislation

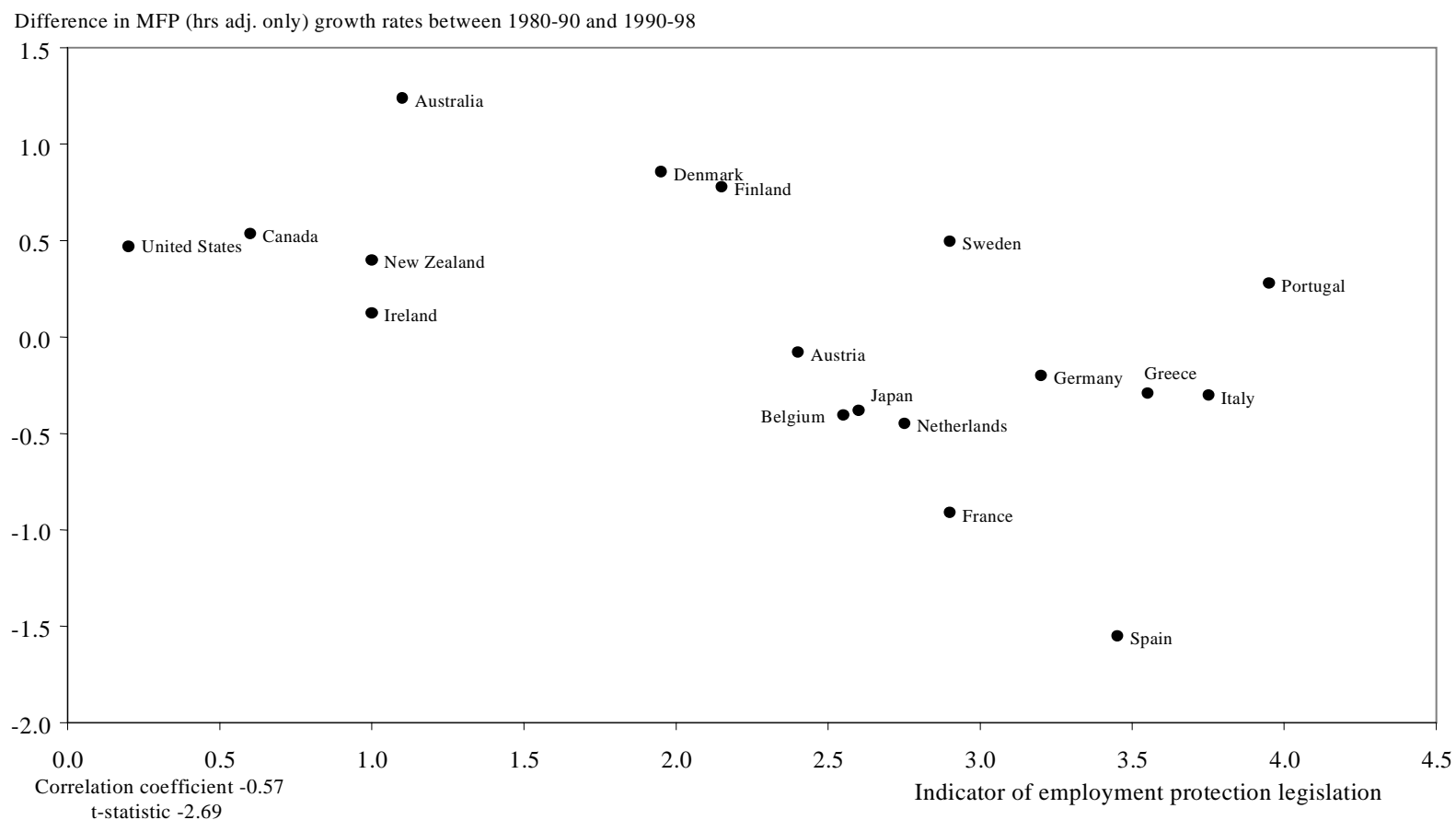

Source: Data on regulation are from Nicoletti et al. (1999). 
Regulation in the labour market can play a role as well. In particular, when employment protection regulations are very strict, firms may become very cautious in adjusting their labour force and this may reduce turnover and/or (expected) returns from investment (Bertola, 1992, Boeri et al., 2000). This might be particularly important in the case of mergers and takeovers. In fact, when successful, they usually bring about painful adjustments in the employed staff, especially managerial and nonproduction workers (Lichtenberg and Siegel, 1991, Hobjin and Jovanovic, 1999). Again on a tentative basis, a significant negative correlation between an indicator of employment protection legislation ${ }^{38}$ and MFP acceleration can be found for the 1990s, as shown by Figure 9.

To sum up, wide disparities in output and productivity patterns among OECD countries can be related to a number of traditional factors, most notably the capability of countries to employ people of working age. This points to the policy and institutional settings of different countries, a subject that the OECD has studied thoroughly in recent years and for which the countries themselves and international organisations (including the OECD) have formulated policy prescriptions. Recent evidence also highlights the importance of new technologies, and specifically ICT, in boosting output and productivity growth. Moreover, the spread of networks (e.g. Internet) is likely to lead to a further boost in the near future, by enabling better communications amongst economic agents. These new potential driving forces of growth require suitable framework conditions. In part, the same policy prescriptions that may allow the traditional factors of growth to work better are likely to be useful to improve framework conditions conducive to ICT and related technologies to further spread and contribute to growth. However, there are likely to be areas of particular importance, and new policy actions may also be required. In this section, we have offered some speculation and tentative evidence of the possible link between some product and labour market regulations, firm dynamics, innovation and MFP growth. These should only be considered as possible issues to be included in the research agenda of the coming years.

38. The indicator of Employment Protection Legislation (EPL) used in Figure 9 is an average of indicators for 1990 and 1998. Other indicators refer to 1998 only, as no other date is available (see Nicoletti et al., 1999). 
ECO/WKP(2000)32

\section{BIBLIOGRAPHY}

AGHION, P. and P. HOWITT (1998), Endogenous Growth Theory, Cambridge, Mass.: The MIT Press.

BAILY, M.N., E.J. BARTELSMAN and J. HALTIWANGER (1996), "Downsizing and Productivity Growth: Myth or Reality?", Small Business Economics, Vol. 8, August, pp. 259-278.

BARRO, R.J. (1998), "Notes on Growth Accounting”, NBER Working Paper No. 6654, Cambridge, MA.

BASSANINI, A. (1999), "Can Science and Agents' Diversity Tie the Hands of Clio?: Technological Trajectories, History and Growth", mimeo.

BASSANINI, A., S. SCARPETTA and I. VISCO (2000), "Knowledge, Technology and Growth: Recent Evidence from OECD Countries", National Bank of Belgium Working Paper No. 6.

BERTOLA, G. (1992), "Labour Turnover Costs and Average Labour Demand", Journal of Labour Economics, Vol. 10, pp. 389-411.

BLS (1993), "Labor Composition and U.S. Productivity Growth, 1948-90", U.S. Department of Labor, Bureau of Labor Statistics, Bulletin 2426, December.

BOERI, T., G. NICOLETTI and S. SCARPETTA (2000), "Regulation and Labour Market Performance", in: G. Galli and J. Pelkmans (eds), Regulatory Reforms and Competitiveness in Europe, Cheltenham, Elgar.

BUTLER, L. (1996), "A Semi-Structural Approach to Estimate Potential Output: Combining Economic Theory with A Time-Series Filter", Bank of Canada Technical Report, No. 76, Ottawa.

CEA (2000), Economic Report of the President - 2000, February.

DAVID, P.A. (1990), "The Dynamo and the Computer: An Historical Perspective on the Productivity Paradox", American Economic Review, Papers and Proceedings, Vol. 80, pp. 315-48.

DAVID, P.A. (1991), "Computer and Dynamo: The Modern Productivity Paradox in a Not-Too-DistantMirror", in OECD (1991), Paris.

DIAMOND, P.A. (1965), "Technical Change and the Measurement of Capital and Output", Review of Economic Studies, Vol. 32, pp. 289-99.

FAZZARI, S.M., R.G. HUBBARD and B.C. PETERSEN (1988), "Financing Constraints and Corporate Investment", Brookings Papers on Economic Activities, I, pp. 141-195.

FISHER, F.M. (1965), "Embodied Technical Change and the Existence of an Aggregate Capital Stock", Review of Economic Studies, Vol. 32, pp. 263-88. 
FISHER, F.M. (1968), "Embodied Technology and the Existence of Labour and Output Aggregates", Review of Economic Studies, Vol. 35, pp. 391-412.

GORDON, R.J. (2000), "Does the "New Economy" Measure up to the Great Inventions of the Past?", Journal of Economic Perspectives, forthcoming.

GORT, M. (1969), “An Economic Disturbance Theory of Mergers”, Quarterly Journal of Economics, Vol. 83, pp. 624-42.

GREENWOOD, J., Z. HERCOWITZ and P. KRUSELL (1997), "Long-Run Implications of InvestmentSpecific Technological Change", American Economic Review, Vol. 87, pp. 342-362.

GREENWOOD, J. and B. JOVANOVIC (1999), “Accounting for Growth”, in: C. Hulten (ed.), Studies in Income and Wealth: New Directions in Productivity Analysis, Chicago: University of Chicago Press for NBER.

GRILICHES, Z. (1963), "The Source of Measured Productivity Growth: US Agriculture, 1940-1960", Journal of Political Economy, Vol. 71, pp. 331-46.

GRILICHES, Z. (1987), "Productivity: Measurement Problems", in J. Eatwell, M. Milgate and P. Newman (eds), The New Palgrave: A Dictionary of Economics, New York: Stockson Press.

HERCOWITZ, Z. (1998), "The "Embodiment" Controversy: A Review Essay", Journal of Monetary Economics, Vol. 41, pp. 217-224.

HOBJIN, B., and B. JOVANOVIC (1999), "The Information Revolution and the Stock Market: Preliminary Evidence", mimeo.

HODRICK, R.J. and E.C. PRESCOTT (1997), "Post-War U.S. Business Cycles: An Empirical Investigation", Journal of Money, Credit and Banking, Vol. 29, No. 1.

JORGENSON, D.W. (1963), "Capital Theory and Investment Behaviour", American Economic Review; Vol. 53, No. 2, May.

JORGENSON, D.W. (1966), “The Embodiment Hypothesis”, Journal of Political Economy; Vol. 74, No. 1, pp. 1-17.

JORGENSON, D.W. and Z. GRILICHES (1967), "The Explanation of Productivity Change", Review of Economic Studies, Vol. 34, No. 3, July.

JORGENSON, D.W. and K.J. STIROH (2000), "Raising the Speed Limit: U.S. Economic Growth in the Information Age", May, Brookings Papers on Economic Activity, forthcoming.

JOVANOVIC, B. and S. LACH (1989), "Entry, Exit and Diffusion with Learning by Doing", American Economic Review, Vol. 79, pp. 690-99.

JOVANOVIC, B. and Y. NYARKO (1996), "Learning by Doing and the Choice of Technology", Econometrica, Vol. 64, pp. 1299-310.

LICHTENBERG, F. and D. SIEGEL (1990), "The Effect of Leverage Buyouts on Productivity and Related Aspects of Firm Behaviour", Journal of Financial Economics, Vol. 26, pp. 165-94. 
MORRISON, C.J. (1999), Cost Structure and the Measurement of Economic Performance, Norwell, MA: Kluwer Ac.

NADIRI, M.I. (1993), “Innovations and Technological Spillovers”, NBER Working Paper No. 4423.

NELSON, R.R. (1964), "Aggregate Production Functions and Medium-Run Growth Projections", American Economic Review, Vol. 54, pp. 575-606.

NELSON, R.R., and S.G. WINTER (1982), An Evolutionary Theory of Economic Change, Cambridge, MA: The Belknap Press of Harvard University Press.

NICOLETTI, G., S. SCARPETTA and O. BOYLAUD (1999), "Summary Indicators of Product Market Legislation with an Extension to Employment Protection Legislation", OECD Economics Department Working Papers, No. 226, OECD, Paris.

OECD (1991), Technology and Productivity: The Challenge for Economic Policy, Paris.

OECD (1996), Industry Productivity - International Comparison and Measurement Issues, Paris.

OECD (1998a), Technology, Productivity and Job Creation - Best Policy Practices, Paris.

OECD (1998b), Science, Technology and Industry Outlook 1998, Paris.

OECD (1999), The OECD Jobs Strategy: Assessing Performance and Policy, Paris.

OECD (2000), A New Economy?: The Changing Role of Innovation and Information Technology in Growth, Paris.

OLINER, S.D. and D.E. SICHEL (2000), "The Resurgence of Growth in the late 1990s: Is Information Technology the Story?", FRB Finance and Economic Discussion Paper, 2000-20, Federal Reserve Board.

ROMER, P.M. (1990), "Endogenous Technological Change”, Journal of Political Economy Vol.98, Supplement, pp. 71-102.

SCARPETTA, S. A. BASSANINI, D. PILAT and P. SCHREYER (2000) "Economic Growth in the OECD Area: Recent Trends at the Aggregate and Sectoral Level", OECD Economics Department Working Papers No. 248, Paris.

SCHREYER, P. (2000), "The Impact of Information and Communication Technology on Output Growth", OECD STI Working Paper, 2000/2.

SILVERBERG, G., G. DOSI and L. ORSENIGO (1988), "Innovation, Diversity and Diffusion: A SelfOrganisation Model", The Economic Journal, Vol. 98, December.

SOLOW, R.M. (1957), "Technical Change and the Aggregate Production Function", Review of Economics and Statistics, Vol. 39, pp. 312-20.

SOLOW, R.M. (1960), "Investment and Technical Progress", in K. Arrow et al. (eds) "Mathematical Methods in the Social Sciences, 1959”, Stanford: Stanford University Press.

WHELAN, K. (2000), “Computers, Obsolescence and Productivity”, February, mimeo. 


\section{ECO/WKP(2000)32}

YORUKOGLU, M. (1998), "The Information Technology Productivity Paradox", Review of Economic Dynamics, Vol. 1, pp. 551-92.

ZECKHAUSER, R. (1968), "Optimality in a World of Progress and Learning", Review of Economic Studies, Vol. 35, pp. 363-65. 


\section{ECONOMICS DEPARTMENT \\ WORKING PAPERS}

258. Average Effective Tax Rates on Capital, Labour and Consumption (October 2000) David Carey and Harry Tchilinguirian

257. The Health Care System in Poland (September 2000) Nathalie Girouard and Yutaka Imai

256. Public Expenditure Reform: The Health Care Sector in the United Kingdom (August 2000) Vincent Koen

255. Regulatory Reform in Road Freight and Retail Distribution (August 2000) Olivier Boylaud

254. Regulation, Market Structure and Performance in Air Passenger Transportation (August 2000) Rauf Gonenc and Giuseppe Nicoletti

253. Policy Interdependence during Economic Transition: the Case of Slovakia 1999-2000 (June 2000) Joaquim Oliveira Martins and Tristan Price

252. E-Commerce: Impacts and Policy Challenges (June 2000) Jonathan Coppel

251. The Implementation and the Effects of Regulatory Reform: Past Experience and Current Issues (June 2000) Rauf Gonenc, Maria Maher and Giuseppe Nicoletti

250. The Concept, Policy Use and Measurement of Structural Unemployment: Estimating a Time Varying NAIRU across 21 OECD Countries

(June 2000) Pete Richardson, Laurence Boone, Claude Giorno, Mara Meacci, David Rae and David Turner

249. Options for Reforming the Spanish Tax System

(June 2000) Isabelle Joumard and Aristomène Varoudakis

248. Economic Growth in the OECD Area: Recent Trends at the Aggregate and Sectoral Level (June 2000) Stefano Scarpetta, Andrea Bassanini, Dirk Pilat and Paul Schreyer

247. Economic Effects on the 1999 Turkish Earthquakes: an Interim Report (June 2000) Alexandra Bibbee, Rauf Gonenc, Scott Jacobs, Josef Konvitz and Robert Price

246. Policy Influences on Economic Growth in OECD Countries: an Evaluation of the Evidence (June 2000) Sanghoon Ahn and Philip Hemmings

245. The Tax System in the Czech Republic (May 2000) Chiara Bronchi and Andrew Burns

244. The Tax System in Norway: Past Reforms and Future Challenges (May 2000) Paul van den Noord 


\section{ECO/WKP(2000)32}

243. A Changing Financial Environment and the Implications for Monetary Policy (May 2000) Paul Mylonas, Sebastian Schich, Gert Wehinger

242. Carbon Emission Leakages: a General Equilibrium View (May 2000) Jean-Marc Burniaux and Joaquim Oliveira Martins

241. The Healthcare System in Hungary

(April 2000) Eva Orosz and Andrew Burns

240. Comparing Semi-Structural Methods to Estimate Unobserved Variables: the HPMV and Kalman Filters Approaches (April 2000) Laurence Boone

239. New Issues in Public Debt Management: Government Surpluses in Several OECD Countries, the Common Currency in Europe and Rapidly Rising Debt in Japan (April 2000) Paul Mylonas, Sebastian Schich, Thorsteinn Thorgeirsson and Gert Wehinger

238. Regulation, Industry Structure and Performance in the Electricity Supply Industry (April 2000) Faye Steiner

237. Regulation, Market Structure and Performance in Telecommunications (April 2000) Olivier Boylaud and Giuseppe Nicoletti

236. Predicting the Evolution and Effects of the Asia Crisis from the OECD Perspective (April 2000) Pete Richardson, Ignazio Visco and Claude Giorno

235. Modelling Manufacturing Export Volumes Equations

A System Estimation Approach

(April 2000) Keiko Murata, David Turner, David Rae and Laurence Le Fouler

234. The Polish Tax Reform

(March 2000) Patrick Lenain and Leszek Bartoszuk

233. The Tax System in Mexico: a Need for Strengthening the Revenue Raising Capacity (March 2000) Thomas Dalsgaard

232. EMU, the Euro and the European Policy Mix

(February 2000) Jonathan Coppel, Martine Durand and Ignazio Visco

231. The Tax System in Japan: a Need for Comprehensive Reform (February 2000) Thomas Dalsgaard and Masaaki Kawagoe

230. The Size and Role of Automatic Fiscal Stabilisers in the 1990s and Beyond (January 2000) Paul van den Noord

229. Enhancing Environmentally Sustainable Growth in Finland (January 2000) Ann Vourc'h and Miguel Jimenez

228. Finance and Growth: Some Theoretical Considerations, and a Review of the Empirical Literature (January 2000) Kotaro Tsuru

227. What the Yield Curves Say about Inflation: Does It Change over Time?

(December 1999) Sebastian Schich 